ROCZNIKI KULTUROZNAWCZE

Tom XI, numer $2 \quad-\quad 2020$

DOI: http://dx.doi.org/10.18290/rkult20112-5

KS. ZBIGNIEW ROLSKI

IRENEUSZ THOMAS

\title{
DZIAŁALNOŚĆ RELIGIJNA I DOBROCZYNNA PRZEWORSKIEGO OŚRODKA KANONIKÓW REGULARNYCH STRÓŻÓW NAJŚWIĘTSZEGO GROBU BOŻEGO W JEROZOLIMIE
}

\section{WPROWADZENIE}

W obszarze treści dotyczących chrześcijańskiej pomocy drugiemu człowiekowi i dobroczynności, czyli religijnej tradycji samarytańskiej, w szczególny sposób jest obecna tajemnica Chrystusowego zbawienia ludzkości, którą Kościół realizuje zwłaszcza poprzez liturgiczne wspomnienie tajemnic Wielkanocnego Misterium Paschalnego. Jest to celebrowane i doskonale widoczne w czasie Triduum Paschalnego i Niedzieli Wielkanocnej. Czcząc boskość Chrystusa w Jego zbawczym dziele, Kościół otacza szczególną czcią Krzyż Święty, na którym dokonało się nasze zbawienie.

Miejscem w wyjątkowy sposób związanym z Misterium Paschalnym jest Bazylika Grobu Pańskiego, obejmująca obiekty upamiętniające górę Golgotę i grotę Grobu. Zarówno Grób Chrystusa w Jerozolimie - świadek Zmartwychwstania Pańskiego, jak i miejsce, gdzie stał Krzyż na Kalwarii, mają nieprzerwaną tradycję kultową i cechy historycznego autentyzmu religijnego ${ }^{1}$.

Ks. ZBIGNIEw Rolski — kapelan Szpitala Rejonowego w Przeworsku i rezydent przy Bazylice Kolegiackiej pw. Ducha Świętego, dawniej Zakonu Bożogrobców w Przeworsku; adres do korespondencji - e-mail: zibirol64@wp.pl. ORCID: https://orcid.org/0000-0002-6423-3298.

Dr Ireneusz Thomas - Uniwersytet Rzeszowski; adres do korespondencji - e-mail: ireneusz thomas@op.pl. ORCID: https://orcid.org/0000-0001-5062-7141.

${ }^{1}$ Por. Eugeniusz DąBRowski, Grób Chrystusa, w: Podręczna encyklopedia biblijna, red. Eugeniusz Dąbrowski (Poznań: Księgarnia Św. Wojciecha, 1960), 433-434; Stanisław Łach, „Miejsce śmierci i Zmartwychwstania Chrystusa", Ruch Biblijny i Liturgiczny 11 (1958), nr 2: 124-134; Efrem GuIŃsKI, „Z historii Grobu świętego, Ruch Biblijny i Liturgiczny 1 (1948, nr 2: 68-69; Aureliusz Borkowski, „O Grobie Bożym (1149-1949)”, Ruch Biblijny i Liturgiczny 2 (1949), nr 3: 165-166. 
Już w starożytności i średniowieczu stawały się obiektami czci wiernych, na co wskazują pierwsze pielgrzymki do Jerozolimy, odbywane mniej więcej już od początku IV wieku, a zwłaszcza najstarszy opis sanktuariów jerozolimskich oraz nabożeństw liturgicznych wielkotygodniowych, zawarty chociażby w relacji Eterii zwanej Sylwią ${ }^{2}$.

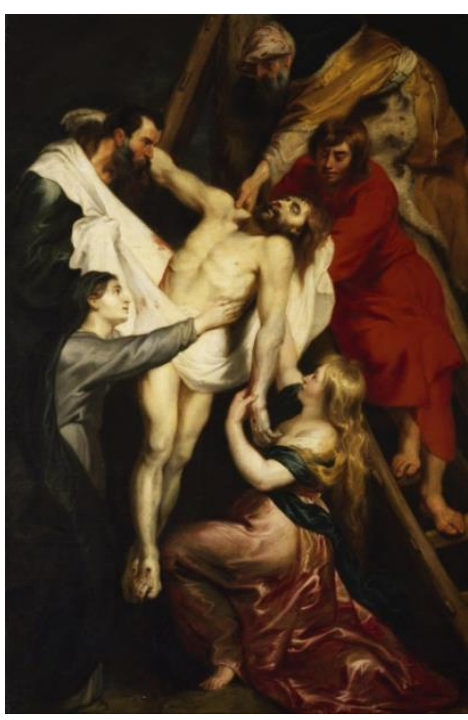

Ryc. 1. Peter Paul Rubens, Zdjęcie z Krzyża, 1610 r.,

(za: commons.wikimedia.org, public domain)

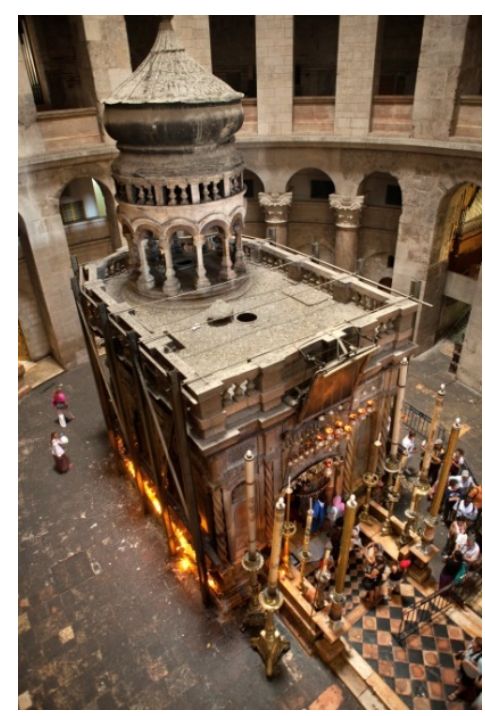

Ryc. 2. Anastasis - edykuła Grobu Pańskiego w Jerozolimie

(za: commons.wikimedia.org, public domain)

Charakterystycznym znakiem związanym z Grobem Pańskim stał się podwójny czerwony krzyż patriarchalny, który wygląda jak krzyż łaciński z jedną dodatkową, krótszą poprzeczką powyżej, która ma symbolizować deskę z napisem „Iesus Nazarenus Rex Iudaeorum” (INRI), umieszczoną na krzyżu nad głową Chrystusa. Według legendy Maryja, Matka Jezusa, oznajmiła Jakubowi Młodszemu stojącemu przy ukrzyżowanym Synu, że zostanie pierwszym biskupem prawowiernych w Jerozolimie oraz stróżem Grobu Chrystusa. Mówiąc to, naznaczyła palcem umoczonym we krwi Jezusa krzyż na szacie Apostoła, dodając ową drugą belkę. Umieszczenie $\mathrm{w}$ tej scenie podwójnego krzyża, używanego potem przez bożogrobców, miało sugerować i podkreślać ścisły związek tego zakonu z propagowaniem kultu i idei Krzyża Świętego. ${ }^{3}$. W tradycji bożo-

\footnotetext{
${ }^{2}$ Por. ETERIA, Pielgrzymka do miejsc świętych, przeł. Władysław Wojciech Szołdrski (Pisma Starochrześcijańskich Pisarzy [PSP] t. 6, Warszawa: ATK, 1970), 160-197.

${ }^{3}$ Por. Jolanta TAlBIERSKA, „Treści ideowe dekoracji monumentalnych kościoła Świętych Apostołów Piotra i Pawła w Nysie, dawniej kościoła klasztornego bożogrobców", Studia Theologica Varsaviensia 23 (1985), nr 1: 179.
} 
grobców istnieją jednak dwie wersje krzyża, będące symbolem tego zakonu. Pierwszy to krzyż jerozolimski, czyli duży grecki krzyż laskowany, między którego ramionami umieszczono cztery małe krzyże greckie. Symbolizuje on pięć ran Chrystusa ukrzyżowanego lub, w innych interpretacjach, Chrystusa i czterech Ewangelistów, cztery strony świata albo Ziemię Świętą i cztery królestwa (Francji, Niemiec, Obojga Sycylii i Anglii), z których wywodziło się rycerstwo biorące udział w krucjatach ${ }^{4}$. Drugi to podwójny czerwony krzyż z dwiema poziomymi belkami, z których górna oznaczała władzę biskupa, dolna - dłuższa - władzę patriarchy. We wczesnym chrześcijaństwie używali go najczęściej patriarchowie i arcybiskupi, dlatego nazywany jest krzyżem metropolitalnym.
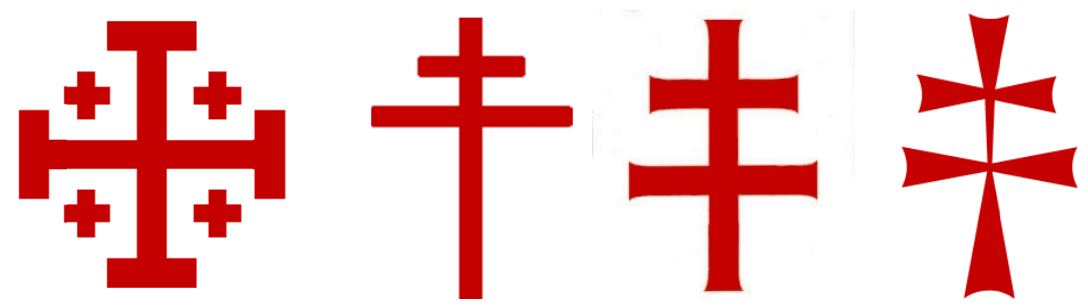

Ryc. 3. Krzyż jerozolimski, krzyż metropolitalny (także karawaka) i dwie odmiany krzyża bożogrobiców (Red.)

Inna nazwa podobnego krzyża to karawaka, od miasta Caravaca w Hiszpanii ${ }^{5}$. Według Zygmunta Glogera ten typ krzyża zaczął się pojawiać wraz napływem pielgrzymów po Soborze Trydenckim, podobno miał go nawet z sobą król Jan III Sobieski podczas bitwy pod Wiedniem, natomiast od XVII i XVIII wieku w Polsce był powszechnie uważany za cudowny środek chroniący od moru i zarazy, dlatego występuje także pod nazwami krzyż choleryczny lub krzyż morowy ${ }^{6}$. W historycznych czasach, kiedy tereny Polski były nawiedzane przez morowe powietrze $\mathrm{i}$ inne epidemie, widok podwójnego krzyża był na tyle częsty na przydrożnych kapliczkach czy drzwiach domów, że - jak wspomina Franciszek Kotula - na terenie diecezji przemyskiej trudno było rozróżnić, które krzyże były bożogrobców, a które miały bronić mieszkańców przez zarazą ${ }^{7}$.

\footnotetext{
${ }^{4}$ Por. Paweł Dudziński, Alfabet heraldyczny (Warszawa: Diogenes, 1997), 103.

${ }^{5}$ Por. Marek KoŁyszko, Wizerunki podwójnego krzyża w kulturze Polskiej (Toruń: Wydawnictwo Naukowe UMK, 2015), 8.

${ }^{6}$ Por. Zygmunt Gloger, Encyklopedja Staropolska Ilustrowana, t. 3: Kapelusz - Pieczęć (Warszawa: Druk P. Laskauera i S-ki, 1902), 8 (hasło: Karawaka, karawika).

${ }^{7}$ Por. Franciszek Kotula, Znaki przeszłości: odchodzace ślady zatrzymać w pamięci (Warszawa: Wydawnictwo: Ludowa Spółdzielnia Wydawnicza, 1976), 145.
} 
Taki znak krzyża nosiły także Kanoniczki Grobu Bożego, których początków należy szukać już w 1114 r. w Saragossie w Hiszpanii ${ }^{8}$. Tradycja przekazała nam informacje o dwóch kierunkach rozwoju zgromadzeń rzymsko-katolickich, które z tajemnicy Bożego Grobu uczyniły kanwę swojego ruchu zakonnego. Również w Kościołach wschodnich mamy specyficzne formy zgromadzeń duchownych i świeckich, których członkowie kontemplują tajemnice religijne oraz prowadzą działalność prospołeczną wzorowaną na średniowiecznych zakonach i organizacjach społecznych (bractwach, np. Ortodoksyjne Bractwo Rycerskie Obrońców Bożego Grobu, ros. Братство Святого Гроба [Bratstvo Svyatogo Groba]).

Niniejszy artykuł podejmuje tematykę liturgii i symboliki zakonu bożogrobców klucza przeworskiego w kontekście charakterystycznych cech kultu i dobroczynności związanych z Bożym Grobem oraz pomocą chorym i umierającym. Splot tych dwóch nurtów chrześcijaństwa odzwierciedla istotne cechy kultury duchowej i materialnej, na które składają się obrzędy liturgiczne związane z uroczystymi obchodami męki, śmierci i zmartwychwstania Jezusa Chrystusa, widoczne szczególnie w oddawaniu czci relikwiom Krzyża oraz fundowaniu budowli Bożego Grobu, zbliżonych do jerozolimskiego oryginału, przy kościołach zakonnych bożogrobców. Owe praktyki religijne wywarły mocny wpływ na kulturę społeczną poprzez propagowanie treści związanych ze śmiercią i oczekiwanym zmartwychwstaniem każdego wierzącego chrześcijanina. Kontemplując tajemnice zmartwychwstania Chrystusa, bożogrobcy zachęcali wiernych do dobroczynnych praktyk wobec chorych i umierających, zapewniając im zarówno opiekę duchową, jak i medyczną. Członkowie bractwa bożogrobców dobrowolnie pomagali potrzebującym pomocy, obłożnie chorym, jak i zmarłym, którym rodziny nie mogły zapewnić godnego pochówku i pamięci modlitewnej po śmierci. Dzięki temu zapewniali wielu godne warunki ostatnich dni życia, wiążąc ich śmierć, nierzadko poprzedzoną cierpieniem, ze zbawczym dziełem Jezusa Chrystusa.

Praca składa się zasadniczo z trzech części. W pierwszej zapoznajemy się z historią działalności zakonnej bożogrobców w Ziemi Świętej i Europie, a w szczególności w Przeworsku, gdzie rozwijała się najmłodsza, czwarta prowincja bożogrobców w Polsce. W drugiej części zostały zaprezentowane szczegółowe elementy liturgii bożogrobców związane z Wielkim Tygodniem

\footnotetext{
${ }^{8}$ Por. „Symbolika Bożogrobców według relacji Chorzowskiego Bractwa Rycerskiego Bożogrobców”, dostęp 10.01.2020, http://www.bozogrobcy.pl/symbolika-bozogrobcow.html oraz „Miechów Bożego Grobu", Diecezja kielecka, dostęp 02.01.2020, http://www.diecezja.kielce.pl/parafie/ miechow-grobu-bozego.
} 
i Niedzielą Zmartwychwstania. W trzeciej natomiast części skupiamy się przede wszystkim na współczesnym przejawach odnawiania kultu Bożego Grobu w Przeworsku, rozwijanego na podstawie historycznych traktatów religijnych bożogrobców, a wspieranego formami lokalnej pobożności oraz pracami konserwatorsko-renowacyjnymi w tutejszym kościele. Artykuł jest więc przyczynkiem do pogłębienia wiedzy na temat działalności bożogrobców w Przeworsku w wymiarze historycznym, religijnym, a w szczególności w aspekcie dobroczynności. W części pracy dotyczącej kultu Grobu Pańskiego autorzy odnieśli się do takich źródeł, jak księgi liturgiczne czy modlitewniki, ale ze względu na trudności z dotarciem do oryginałów tych źródeł z racji chociażby miejsca ich przechowywania (np. Biblioteka Watykańska), zaistniała konieczność posługiwania się danymi z drugiej ręki, zawartymi w opracowaniach cytowanych autorów.

\section{POCZĄTKI KULTU BOŻEGO GROBU Z JEROZOLIMY}

Od pewnego momentu jednymi z najważniejszych opiekunów kultu Grobu Pańskiego w Europie byli przede wszystkim rycerze i zakonnicy tworzący Zakon Rycerski Grobu Bożego w Jerozolimie (Ordo Equestris Sancti Sepulcri Hierosolymitani, OESSH), w Polsce znany także jako Zakon Kanoników Regularnych Stróżów Grobu Chrystusowego (Canonici Regulares Custodes Sanctissimi Sepulchri Hierosolymitani), popularnie zwanych bożogrobcami. Historyczne początki tego zakonu są nieco niejasne, chociaż zgodnie z nieudokumentowaną tradycją sięgają czasów pierwszej krucjaty. W istocie pierwszy dokument potwierdzający inwestyturę tych rycerzy, określanych jako Stróże Najświętszego Grobu Jerozolimskiego, pochodzi z 1336 r. Od tego pierwszego dokumentalnego świadectwa istnienia Zakonu, czyli od XIV wieku, papieże stopniowo i regularnie wyrażali swoje pragnienie prawnej aneksji tej organizacji zakonnej do Stolicy Apostolskiej. Zakon Kanoników Regularnych Grobu Świętego w Jerozolimie zawsze korzystał z ochrony papieży, którzy przez wieki go reorganizowali, rozszerzając i wzbogacając jego przywileje, do momentu aż papież Klemens VI w 1342 r. powierzył pieczę nad Grobem Świętym braciom franciszkańskim ${ }^{9}$, a kiedy Zakon ten przeżył poważny kryzys pod koniec XV wieku, papież Innocenty VIII w 1489 r. inkorporował bożogrobców do Zakonu Joannitów (zwanych później Kawalerami Maltańskimi).

\footnotetext{
9 „Order of the Holy Sepulchre of Jerusalem”, The Holy See, dostęp 20.07.2020, http:// www. vatican.va/roman_curia/institutions_connected/oessh/en/cenni_storici_en.html..
} 
W Królestwie Polskim natomiast $\mathrm{w}$ tamtych czasach bożogrobcy przeżywali okres swojego znacznego rozwoju. Pod popularną nazwą bożogrobców funkcjonowały lub funkcjonują trzy instytucje zakonne: zakon klerycki Kanoników Regularnych Stróżów Grobu Świętego Jerozolimskiego, grupa rycerzy, będących ich militarnym wsparciem i pod koniec XV wieku przekształconej w Zakon Rycerzy Grobu Świętego, oraz współcześnie działające stowarzyszenie osób duchownych i świeckich jako Zakon Rycerski Grobu Świętego Jerozolimskiego (w Polsce pod nazwą Zakon Rycerski Grobu Bożego w Jerozolimie). Do Polski zakon klerycki bożogrobców został sprowadzony z Jerozolimy już w drugiej połowie XII wieku przez Jaksę, księcia serbo-łużyckiego (z Kopniku) i dygnitarza małopolskiego. Jaksa ufundował im kościół i klasztor w Miechowie. To miejsce, z repliką Grobu Bożego w Jerozolimie, z każdym dziesięcioleciem zyskiwało na znaczeniu religijnym ${ }^{10}$. Zarówno książęta piastowscy, jak i rycerstwo polskie chętnie odwiedzało miechowskie sanktuarium, obdarowując je wieloma donacjami.

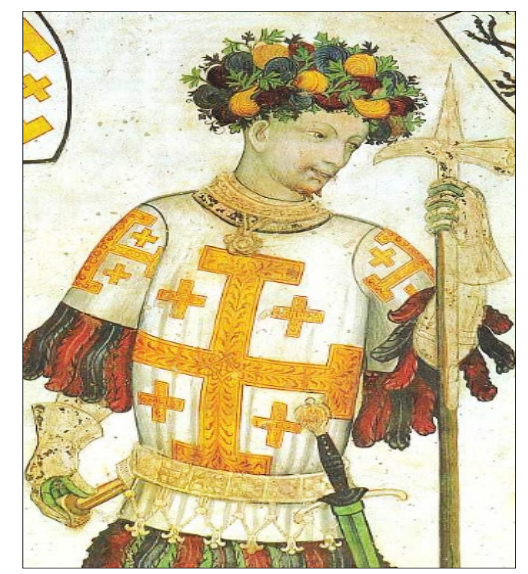

Ryc. 4. Książę Godefroy de Bouillon (1058-1100), Obrońca Grobu Świętego, współtwórca zakonu bożogrobców.

Malowidło Maestro del Castello della Manta, Cuneo, Włochy (za: commons.wikimedia.org, public domain)

Ta wyjątkowa wspólnota kanonicza powstała w Ziemi Świętej w okresie wypraw krzyżowych za sprawą Gotfryda z Bouillon ${ }^{11}$, który przy Świętym Grobie w Jerozolimie utworzył kapitułę, stawiającą sobie za cel opiekę nad

\footnotetext{
${ }^{10}$ Por. Henry Skorowski, Protoplaści rodu Jaxa Bykowskich (Warszawa: UKSW, 2017), 67.

${ }^{11}$ Por. „Gotfryd z Bouillon”, Wikipedia, dostęp 10.07.2020, https://pl.wikipedia.org/wiki/ Gotfryd _z_Bouillon.
} 
tym świętym miejscem oraz rzeszami pielgrzymujących tu wiernych. Zakon przyjął regułę św. Augustyna, nadaną mu w 1114 r. przez patriarchę jerozolimskiego Arnolda de Rohes. Wkrótce też, w 1122 r., został zatwierdzony przez papieża Kaliksta II. Już jednak w 1291 r., po upadku Królestwa krzyżowców, bożogrobcy musieli opuścić Palestynę. Na późniejszy okres przypada natomiast bujny rozkwit tego zakonu w Europie, kiedy to bożogrobcy licznie rozprzestrzenili się na stałe po wielu królestwach. W XV wieku mieli już w Europie około dwustu placówek ${ }^{12}$. Współpracowali zwłaszcza z komandoriami Zakonu Templariuszy oraz Zakonu Szpitala Najświętszej Maryi Panny Domu Niemieckiego w Jerozolimie, czyli Krzyżaków, i z tego też m.in. powodu w średniowiecznej Polsce również bożogrobców zwano dość powszechnie krzyżakami (z niemieckiego Kreuzherren) ${ }^{13}$.

Aby lepiej zrozumieć znaczenie kultu religijnego, związanego $\mathrm{z}$ architekturą budynku kościoła zawierającego Boży Grób, w tym także genezę Sepulchrum Domini w Przeworsku, będącego tematem niniejszego opracowania, wypada przyjrzeć się pokrótce dziejom jego jerozolimskiego Pierwowzoru.

Wiadomo, że bazylika Grobu Chrystusa w Jerozolimie od czasów cesarza rzymskiego Konstantyna Wielkiego, z którego polecenia ją wybudowano, wielokrotnie ulegała zniszczeniu i wielokrotnie ją restaurowano. Pierwszy raz odrestaurowano Grób Pański w Jerozolimie po jego zniszczeniu przez Persów w 614 r. Następna przebudowa Grobu miała miejsce za panowania cesarza bizantyjskiego Konstantyna IX Monomacha (1042-1048). Wreszcie ponownej przebudowy dokonano za czasów krzyżowców po 1149 r. ${ }^{14}$ Ostatniej znaczącej renowacji Bożego Grobu w Jerozolimie dokonali franciszkanie w 1555 r. Nie zmieniła ona w zasadniczego wyglądu miejsca złożenia ciała Chrystusa po Jego śmierci, „niemego świadka” Jego zmartwychwstania.

Stan Grobu Jerozolimskiego we wczesnych latach odzwierciedlają dość liczne przekazy ikonograficzne, m.in Bernarda Breyde, rycerza Grunemberga, a także kopie architektoniczne, z których za najdokładniejszą uważa się budowlę z Görlitz z 1500 r. Do tych kopii zalicza się także relikwiarz w kształcie Grobu Jerozolimskiego podarowany w 1584 r. przez św. Karola Boromeusza kardynałowi Andrzejowi Batoremu, ówczesnemu generałowi bożogrobców ${ }^{15}$.

\footnotetext{
${ }^{12}$ Por. Piotr PĘKALSKI, O poczatku, rozkrzewianiu i upadku Zakonu XX. Kanoników Stróżów Świętego Grobu Jerozolimskiego (Kraków: W drukarni C.K. Uniwersytetu Jagiellońskiego, 1867; repr. Mielec: Zakład Poligraficzny Z. Gajek, 2013), 14.

${ }^{13}$ Warto przypomnieć, że członkowie wszystkich tych trzech zakonów nosili na zakonnych płaszczach wizerunek krzyża, różnego kształtu i koloru.

${ }^{14}$ Por. GLIŃSKI, „Z historii Grobu świętego”, 68-69; BoRkOwSKI, „O Grobie Bożym”, 165-168.

${ }^{15}$ Por. Jerzy ŁozIŃski, „Miechowskie Sepulchrum Domini”, Biuletyn Historii Sztuki 31 (1969): $158-159$.
} 
Istnieje przypuszczenie, że ten właśnie relikwiarz stanowił wzór także dla przeworskiej kopii Sepulchrum Domini ${ }^{16}$.

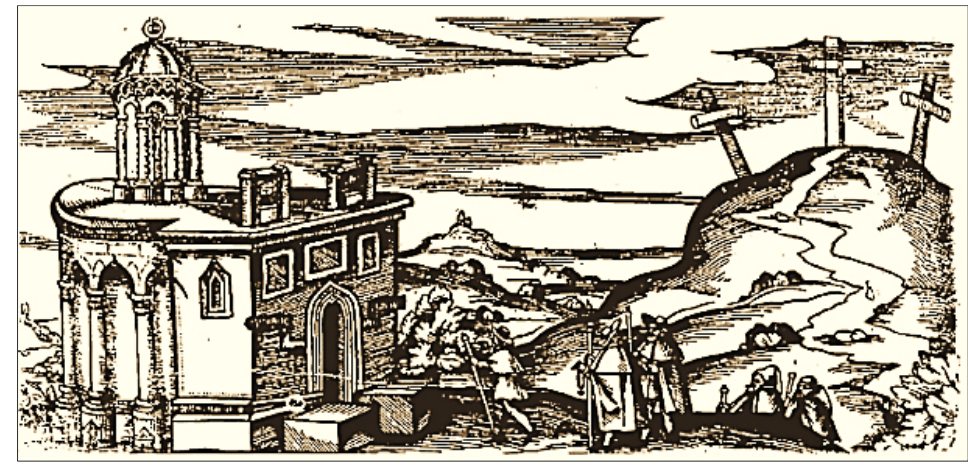

Ryc. 5. Christoph Kueffler, Boży Grób w Görlitz, Berlin 1642.

Do przykładów wiernych kopii Grobu Chrystusowego w Europie należy wspominana budowla z Görlitz, która uchodzi za najdokładniejszą kopię Grobu Jerozolimskiego. Podobnie również monument znajdujący się w kościele św. Anny w Augsburgu i Sepulchrum Domini w kaplicy Rucellai przy kościele św. Pankracego we Florencji. Ta ostatnia budowla jest uważana przez historyków sztuki za zgodną z domniemanym wyglądem Grobu w Jerozolimie za czasów cesarza Konstantyna Wielkiego ${ }^{17}$. Schyłek okresu średniowiecza przyniósł $\mathrm{w}$ liturgii rzymsko-katolickiej szczególnie bujny rozkwit kultu i pobożności związanej z Męką i Śmiercią Chrystusa. Wiąże się z tym praktyka architektonicznego naśladownictwa miejsc świętych, które były pamiątkami Męki i Śmierci Pana. Mamy tego liczne przykłady także w różnych rejonach świata. Kopią Jerozolimskiej bazyliki Grobu Pańskiego jest kościół Anastasis w Konstantynopolu. W Europie kopię jerozolimskiego sanktuarium Grobu stanowi też kościół Świętego Krzyża Jerozolimskiego w Rzymie. We Włoszech spotykamy także cały kompleks siedmiu kościołów przy klasztorze św. Stefana w Bolonii. Pochodzą one z VII wieku i są naśladownictwem palestyńskich miejsc świętych ${ }^{18}$.

Szczególnym przykładem odtwarzania miejsc związanych z błogosławioną Męką i Śmiercią Jezusa, w tym także Jego Grobu, były i są kalwarie

\footnotetext{
${ }^{16}$ Por. Zbigniew PĘcKowski, Miechów. Studia z dziejów miasta i ziemi miechowskiej do roku 1914 (Kraków: Wydawnictwo Literackie, 1967), 368.

${ }^{17}$ Ibid., 161-166.

${ }^{18}$ Por. Jerzy Józef Kopeć, Droga Krzyżowa. Dzieje nabożeństwa i antologia wspótczesnych tekstów (Poznań: Księgarnia Św. Wojciecha, 1975), 47.
} 
oraz golgoty. Po raz pierwszy w architekturze przestrzennej kalwarie pojawiają się w Europie w XV wieku. Genezy kalwarii należy upatrywać w stale rosnącym ruchu pielgrzymkowym do miejsc świętych w Jerozolimie. W ówczesnych warunkach politycznych pielgrzymować do Jerozolimy mogli tylko nieliczni, zamożni, wierni, a poza tym Jerozolima po klęsce wypraw krzyżowych pozostawała w rękach Turków. Podjęto zatem starania w celu przybliżenia wiernym w Europie miejsc świętych z Palestyny oraz ożywienia przez to kultu pasyjnego. Budowano więc coraz liczniejsze lokalne kalwarie, czyli dla chrześcijan miejsca wyjątkowo mocno związane z Męką Chrystusa, w których architekturze i rzeźbach przedstawiane są wydarzenia pasyjne ${ }^{19}$.

Co istotne, kalwarie na terenie Europy powstawały z reguły na terenach wyżynnych, z krajobrazem przypominającym ukształtowanie wzgórz położonych wokół Jerozolimy. W Europie mamy obecnie następujące kalwarie: w pobliżu klasztoru dominikańskiego Scala Coeli w Kordobie (wybudowana w 1420 r.), w Sacro Monte koło Vercello (ok. 1493 r.), w Koblencji (1495 r.), w Bambergu (ok. 1500 r.), w Averdoro w Nadrenii (1501 r.), we Fryburgu Szwajcarskim (1511 r.), w Romans w południowej Francji (pocz. XVII wieku), ponadto w Schwartz koło Innsbrucka, Toblach w Tyrolu, Walencji, Lovanium, Metz, Orta, Rhon, Plougastel i Santo Monte koło Varese.

Także w Polsce utworzono sporą liczbę kalwarii, najbardziej zaś znana i najstarsza jest ta w Kalwarii Zebrzydowskiej, powstała w latach 16081617. Jej fundatorem był magnat Mikołaj Zebrzydowski. Ma 50 stacji (kapliczek i kościółków). Za jej przykładem zaczęto budować nowe miejsca kultu Męki Pana Jezusa. Należy tu wymienić kalwarię w Pakości, budowaną w latach 1629-1635, nieistniejącą już tzw. kalwarię żydowską na Suwalszczyźnie, ufundowaną w 1640 r., i nieco późniejszą w Gordach na Żmudzi (1642 r.), na Pomorzu w Wejcherowie (1647 r.), na Podkarpaciu szczególnie znana jest Kalwaria Pacławska (1667 r.), na Mazowszu — w Górze Kalwarii (1672 r.), na Śląsku — w Wambierzycach (1681 r.), na Górze św. Anny (1700-09 r.), w Krzeszowie (1738 r.) i w Głuchołazach (1859 r.), na Warmii — w Głotowie (1878-1894), w Wielkopolsce — w Ujściu nad Notecią (1899 r.) oraz w Panewnikach koło Katowic, a także w Obornikach Wielkopolskich, Piekarach czy Zawoi ${ }^{20}$.

\footnotetext{
${ }^{19}$ Por. Franciszek Mróz, „Sanktuaria i kaplice Bożego Grobu w Polsce”, Peregrinus Cracoviensis 2000, z. 8: 107 .

${ }^{20}$ Por. Kopeć, Droga Krzyżowa, 48-49, 54-58; Władysław SMereKa, Drogi Krzyżowe. Rys historyczny i teksty. Studium pasyjne (Kraków: Polskie Towarzystwo Teologiczne, 1968), 83-86.
} 


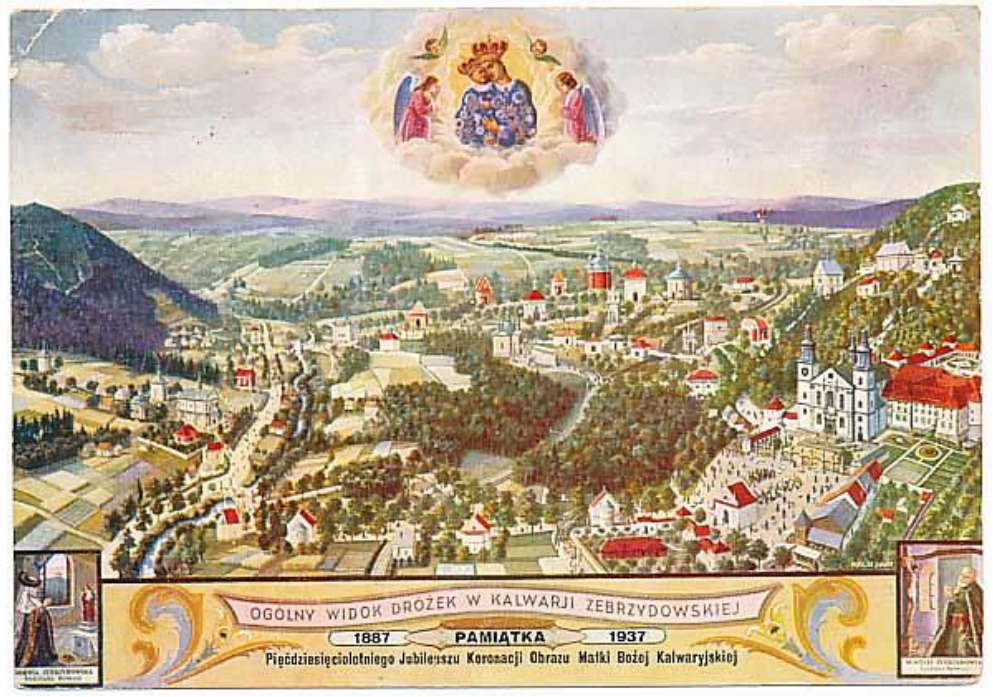

Ryc. 6. Kalwaria Zebrzydowska, karta okolicznościowa z 1937 r. (zbiory własne)

Wraz z budową nowych kalwarii zmieniał się także charakter sprawowanego w nim kultu. Do kaplic poświęconych Chrystusowi dołączano bowiem, już w pierwszej połowie XVII wieku, kaplice poświęcone Matce Bożej. Tym sposobem kalwarie stawały się także ośrodkami kultu maryjnego, czego wyraźnym przykładem są Kalwaria Zebrzydowska i Kalwaria Pacławska.

Inną formą odtwarzania miejsc pasyjnych są przedstawienia pojedynczych miejsc świętych. Oryginalnym tego przykładem był tzw. Ogrójec znajdujący się pomiędzy bazyliką Mariacką a kościołem św. Barbary w Krakowie czy podobne przedstawienie przy także krakowskim kościele pw. Bożego Ciała ${ }^{21}$.

Obiektem sakralnym jednak, który był tematem największej liczby dziel architektury, stał się Grób Chrystusa. Pamiętajmy, że obok wiernych kopii tego wyjątkowego jerozolimskiego grobu w wielu kościołach powstawały przedstawienia niemające pod względem architektonicznym zbyt wiele wspólnego z jerozolimskim pierwowzorem. Źródłem inspiracji dla autorów przedstawień Grobu Chrystusa były opisy miejsca spoczynku Chrystusa, przekazywane także przez pielgrzymów, duchownych i rycerzy biorących udział w wyprawach krzyżowych i robiących przy okazji pomiary, a także tworzących szkice, a nawet modele Grobu Jerozolimskiego.

\footnotetext{
${ }^{21}$ Por. Kopeć, Droga Krzyżowa, 47.
} 
Biorąc pod uwagę tylko te obiekty, które były wiernymi kopiami Grobu Pańskiego, trzeba zwrócić uwagę na fakt, że w różnych przypadkach kopiowano różne elementy bazyliki jerozolimskiej: sam sarkofag grobowy albo mieszczącą go kaplicę - mauzoleum osłonięte baldachimowym cyborium lub kopułową rotundę, w której centrum znajdowała się kaplica. Skutkiem niejasności w opisach Grobu było zjawisko tzw. kontaminacji, czyli łączenia cech kaplicy Grobu z elementami rotundy osłaniającej Grób. Powstały w ten sposób obiekt określano mianem Sanctum Sepulchrum. Zjawisko kontaminacji wyjaśnia więc spore różnice $\mathrm{w}$ architekturze poszczególnych przedstawień Grobu Chrystusa. Różnice te wynikają chociazby z faktu, że Sepulchrum Domini w Jerozolimie ulegało licznym przeobrażeniom, związanym ze wspomnianymi już zniszczeniami i rekonstrukcjami Grobu i jego otoczenia. Poszczególne kopie przedstawiają zaś wygląd Grobu z określonego okresu jego dziejów, a także noszą cechy ujęcia architektonicznego, w jakim powstawały ${ }^{22}$.

Źródła archiwalne informują nas, że rycerze i zakonnicy Zakonu Bożogrobców na terenach Królestwa Polskiego pojawili się najprawdopodobniej już w 1163 r., sprowadzeni przez Jaksę z Miechowa, uczestnika II wyprawy krzyżowej $^{23}$. Bożogrobcy, rycerze i zakonnicy, początkowo działali przede wszystkim w Palestynie, w Polsce zaś ich pierwszym i macierzystym klasztorem został ten $\mathrm{w}$ Miechowie $^{24}$, stąd też w naszym kraju bożogrobców powszechnie nazywano miechowitami. W okresie od XII do XVIII wieku zakładali oni liczne klasztory, szkoły i szpitale oraz przytułki dla podróżnych i ubogich ${ }^{25}$. Warto przy okazji wspomnieć, że dla rozwoju szpitalnictwa przykościelnego spore zasługi mieli także zakonnicy ze Zgromadzenia Ducha Świętego (duchaków), stąd być może taka liczba kościołów erygowanych właśnie pod patronatem Ducha Świętego. Duchacy także stosowali regułę św. Augustyna, było ona jednak rozszerzona o czwarty ślub: służeniu biednym i chorym ${ }^{26}$.

$\mathrm{Na}$ ziemiach polskich bożogrobcy utworzyli gęstą sieć klasztorów, korzystając z licznych nadań możnowładczych, w pierwszej kolejności w Mało-

\footnotetext{
${ }^{22}$ Por. ŁozIŃski, „Miechowskie Sepulchrum Domini”, 155-166.

${ }^{23}$ Jej inicjatorami byli św. Bernard z Clairvaux i papież Eugeniusz III. Główną przyczyną jej zorganizowania było przejęcie przez muzułmanów Edessy. Była to pierwsza paneuropejska krucjata do Jerozolimy prowadzona przez królów francuskiego, Ludwika VII, i niemieckiego - Konrada III. Udział w niej wziął też Fryderyk Barbarossa, późniejszy organizator III wyprawy krzyżowej.

${ }^{24}$ Por. Kasper Niesiecki, Herbarz Polski (Warszawa: WAiF, 1979, repr.), 33.

${ }^{25}$ Por. Jan KwaK, „Szpitale w miastach górnośląskich”, Limes 1 (2008): 20.

${ }^{26}$ Por. Leon WachHolz, Szpitale krakowskie 1220-1920. Cz. 1 (Kraków: Towarzystwo Miłośników Historii i Zabytków Krakowa, 1921), 6.
} 
polsce. Ich pierwszy dobrodziej, wspominany już Jaksa z Miechowa, w swoim nadaniu przekazał im Miechów, Zagórzyce i Komorów. Bożogrobcy zajmowali się prowadzeniem hospicjów i szkół, a w sferze obrzędowej propagowali kult Grobu Pańskiego, czego oprawę stanowiły niezwykle uroczyste nabożeństwa pasyjne ${ }^{27}$. Do bazyliki Grobu Pańskiego w Miechowie, gdzie znajdowała się cudowna relikwia w postaci kamienia z grobu Chrystusa w Jerozolimie, ciągnęły przez lata liczne grupy pielgrzymów.

$\mathrm{Na}$ Śląsku pierwsze fundacje bożogrobców są związane z postacią Wojsława, brata biskupa krakowskiego Gedki. Nadał on bożogrobcom dwie wsie w diecezji wrocławskiej, które ci jednak zbyli przed 1198 r. Początek ich właściwej śląskiej ekspansji należy datować na 1223 r., kiedy to $\mathrm{z}$ nadania biskupa wrocławskiego Wawrzyńca przejęli szpital w Nysie, przy którym zapewne powstał jednocześnie konwent. W 1257 r. znaleźli się, obok norbertanów, cystersów i dominikanów, w gronie zgromadzeń, które korzystały z hojności księcia opolsko-raciborskiego Władysława. Fundację zatwierdził 24 VII 1296 r. biskup wrocławski Romka. Godząc się na odprawianie przez zakonników nabożeństw i grzebanie zmarłych przy hospicjum, hierarcha zastrzegł jednak, że sakramentów i ostatniej posługi chorym i zmarłym z miasta będzie udzielał proboszcz miejski lub jego wikariusze ${ }^{28}$. Mieszczanie raciborscy, wyrażający taką wolę, mogli jednak znaleźć miejsce wiecznego spoczynku również przy szpitalu Świętego Krzyża ${ }^{29}$. W tamtejszym kościele do dzisiaj znajduje się pamiątka po bożogrobcach — łacińska inskrypcja, która w tłumaczeniu na język polski brzmi: „Jakub Młodszy, apostoł, biskup Jerozolimy, założyciel Zakonu Stróżów Najświętszego Grobu Pańskiego w Jerozolimie z podwójnym czerwonym krzyżem".

Oprócz zwykłego duszpasterstwa chorych i umierających miechowici zajmowali się głównie fachowym szpitalnictwem, polegającym wówczas przede wszystkim na zapewnianiu podstawowej opieki medycznej, także w trakcie epidemii, ziołolecznictwie oraz oferowaniu prostych formom pomocy społecznej, skierowanych głównie dla pielgrzymów, chorych i niedołężnych ${ }^{30}$. Sama

\footnotetext{
${ }^{27}$ Por. Skorowski, Protoplaści rodu Jaxa Bykowskich, 62

${ }^{28}$ Grzegorz Wawoczny, „Przy zamku stał kiedyś Grób Pański na wzór jerozolimskiego, a przy pl. Mostowym klasztor bożogrobców”, Nasz Racibórz, dostęp 19.07.2020, https:/www.naszraciborz.pl/ site/art/5-styl-zycia/14-historia/73208-przy-zamku-stal-kiedys-grob-panski-na-wzor-jerozolimskiego-a-przy-pl--mostowym-klasztor-bozogrobcow".

${ }^{29}$ Por. Norbert MiKA, „Bożogrobcy raciborscy w średniowieczu”. W: Klasztor w mieście średniowiecznym i nowożytnym, red. Marek Derwich, Anna Pobóg-Lenartowicz i Krzysztof Guzikowski (Wrocław, Opole: DiG, 2000), 422.

${ }^{30}$ Por. Zbigniew PĘcKowski, „Bożogrobcy. W Polsce”, w: Encyklopedia katolicka, t. 2 (Lublin: TN KUL, 1989), kol. 881; TENŻE, Miechów. Studia z dziejów miasta i ziemi miechowskiej do
} 
tradycja łączenia postaw dobroczynności wobec ubogich i ciężko chorych ma więc $\mathrm{w}$ chrześcijaństwie długą tradycję, $\mathrm{z}$ której wynika, że jednymi z pierwszych, którzy brali takie osoby pod opiekę, byli biskupi i wyżsi duchowni zakonni. Gdy chodzi o szpitale, to początkowo były to także instytucje wyłącznie kościelne. Równocześnie, choć zwykle w osobnych pomieszczeniach lub budynkach, prowadzono w nich działalność dobroczynną dla ubogich, zapewniając im skromne wyżywienie i odzież. Z upływem wieków te dwie specjalności zaczęły się rozchodzić, na co miała wpływ polityka władz miejskich, które przejmując pewne prerogatywy administracyjne, wprowadzały do instytucji kościelnych własnych przedstawicieli ${ }^{31}$.

Tradycja bożogrobców na ziemiach polskich stanowi jeden $\mathrm{z}$ bardziej interesujących wątków tej historii. Ten zakon wprowadził po raz pierwszy w tej części Europy profesjonalny system lecznictwa szpitalnego dla ubogich. Oczywiście osoby majętne mogły pozwolić sobie na zamawianie wizyt domowych, pozostała, zazwyczaj uboga większość była skazana albo na domorosłych znachorów, albo właśnie zakonników, zazwyczaj znających się na rzeczy w wyniku wieloletniej praktyki także medycznej, chociażby przez służbę w oddziałach krzyżowców na terenie Ziemi Świętej w Palestynie.

Zgodę na sprowadzenie bożogrobców na placówkę duszpasterską w Przeworsku, w ufundowanym kościele św. Katarzyny, uzyskała w 1394 r. (lub w 1396 r.) magnacka rodzina Tarnowskich, realizująca politykę dworu królewskiego umacniania chrześcijaństwa na terenach Rusi Czerwonej. Bożogrobcy zostali tu sprowadzeni dzięki staraniom ówczesnego właściciela miasta Jana Amosa z Tarnowa (Tarnowskiego) ${ }^{32}$, sprawującego funkcję wojewody sandomierskiego, właściciela klucza jarosławskiego oraz starosty generalnego Rusi ${ }^{33}$. Była to także zapewne jedna $\mathrm{z}$ ostatnich prób zademonstrowania roszczeń do Rusi Halickiej biskupów lubuskich, którego efektem

roku 1914 (Kraków: Wydawnictwo Literackie, 1967), 12-14; Mieczysław ToBiAsz, „Bożogrobcy w Miechowie (w 800-lecie sprowadzenia do Polski)", Nasza Przeszłość 17 (1963): 5-10.

${ }^{31}$ Por. Zofia PodgóRsKa-KLAwe, Od hospicjum do wspótczesnego szpitala (Warszawa: Zakład Narodowy im. Ossolińskich, 1981), 9.

32 Jarosław ZBROŻEK, „Jan Amor Tarnowski (1488-1561) - hetman wielki koronny i właściciel miasta Tarnowa”, Moje miasto Tarnów, 4.04.2013, dostęp 19.07.2020, http://www.mmtarnow.com/ 2013/04/jan-amor-tarnowski-1488-1561-hetman.html.

${ }^{33} \mathrm{~W}$ watykańskich dokumentach archiwalnych Bullarium Poloniae znalazła się wzmianka, że jednymi z pierwszych nadań dla Jana z Tarnowa, kustoszowi kościoła NMP w Sandomierzu, były beneficja z wakatujących dekanii i kanonii w Krakowie, wypraszane u papieża Bonifacego IX przez polską królową Jadwigę. Por. Michał MACHEJEK, „Materiały źródłowe zakonu bożogrobców w archiwach watykańskich", w: Bożogrobcy w Polsce, red. Cyprian Wilanowski (Miechów, Warszawa: IW PAX, 1999), 191. 
było wydane w 1393 r. zezwolenie biskupa Jana Maraza (należącego do zakonu bożogrobców) na założenie parafii w Przeworsku.

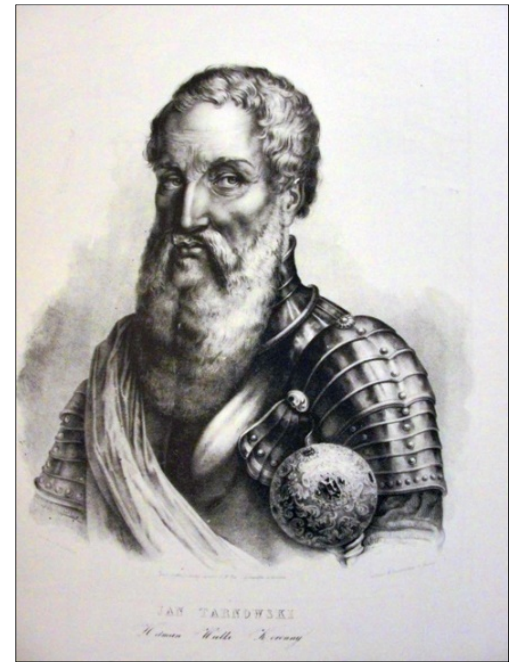

Ryc. 7. Jan Amor Tarnowski (1488-1561).

Litografia Steffens, autor grafiki nieznany. Nakładem Żupańskiego

(za: http://www.mmtarnow.com/2013/04/jan-amor-tarnowski-1488-1561-hetman.html)

Sieć szpitali dla ubogich ziemi przemyskiej powstawała stopniowo, najpierw w większych, znacznie później w mniejszych miastach i na wsiach. Zmienne dzieje pogranicza Rusi Czerwonej sprawiały, że organizacje kościelne zaczęły tu docierać stosunkowo późno wraz z organizacją tutejszej diecezji (1375 r.). Teren ten był również słabo penetrowany misyjnie, zwłaszcza gdy chodzi o zakony - franciszkanów, dominikanów i bożogrobców. Tym ostatnim powierzono regularne parafie, zajmowali się więc głównie duszpasterstwem misyjnym, a tylko w jego ramach szpitalnictwem ${ }^{34}$.

Dzięki wsparciu biskupa przemyskiego Macieja Janiny parafia w Przeworsku została erygowana 28 kwietnia 1393 r. przy istniejącym na tzw. Małym Rynku drewnianym kościółku pod wezwaniem św. Katarzyny. W następnym roku Jan Amos z Tarnowa ostatecznie przekazał tenże kościół pod zarząd bożogrobców. Zakonnikom w użytkowanie zostały przekazane także tereny tzw. Kniaziego Grodziszcza, które przeznaczono pod budowę projektowanego klasztoru. Ponieważ kościółek św. Katarzyny okazał się zbyt

\footnotetext{
${ }^{34}$ Por. Zdzisław BudzyŃski, Dzieje opieki społecznej w ziemi przemyskiej i sanockiej (XVXVIII w.) (Przemyśl, Kraków: Polskie Towarzystwo Historyczne, 1987), 30-31.
} 
mały na potrzeby duszpasterskie, które sprawowało początkowo sześciu zakonników, dlatego w 1430 r. ówczesny właściciel miasta Rafał z Tarnowa oraz jego syn, także Rafał, właściciel Jarosławia i Przeworska, kasztelan sandomierski i marszałek Królestwa Polskiego, rozpoczęli budowę nowego kościoła na terenie dawnego Kniaziego Grodziszcza. Budowa trwała do 1473 r. $^{35}$ Co istotne dla rozwoju parafii bożogrobców w Przeworsku, otrzymali oni również zezwolenie na zatrzymanie pobieranej dziesięciny biskupiej, odtąd przeznaczonej na utrzymanie parafii.

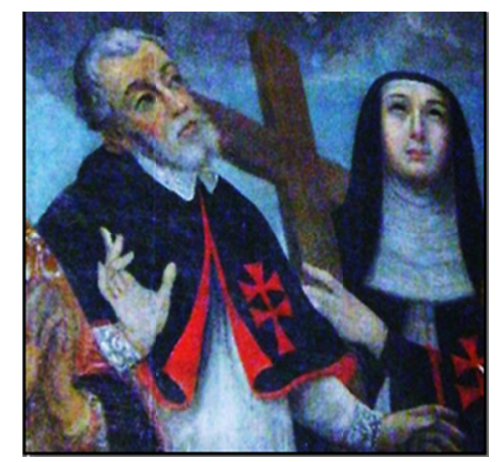

Ryc. 8. Fragment obrazu Tomasza Dolabelli Adoracja Trójcy Świętej i Matki Bożej przez Wszystkich Świętych połązona z chwała Zakonu Bożogrobców, 1643. Fara w Leżajsku (za: http://podkarpackahistoria.pl/bozogrobcy)

Konwent przeworski należał do znaczniejszych placówek bożogrobców w Polsce, pełniąc przy tym główną siedzibę administracji najmłodszej, czwartej prowincji, ruskiej, Zakonu Bożogrobców w Polsce. Układ całej komandorii na Ziemi Przeworskiej miał wyjątkowo interesujący układ przestrzenny z wyraźnymi cechami linii utrzymującej potencjalną granicę etniczną i religijną w dolnym biegu rzeki San, flankując jej lewobrzeżne tereny w kierunku Rzeszowa i dalej do Krakowa oraz tym samym główny szlak handlowy i podróżny wzdłuż Traktu Królewskiego (Via Regia) z Krakowa do Lwowa. Uposażenie magnackie czyniło więc z tej parafii najzamożniejszą spośród wszystkich w diecezji przemyskiej ${ }^{36}$.

Siedzibę komandorii w Przeworsku wspierały dwa najbliższe kościoły filialne w Gniewczynie i Urzejowicach. Szczególnie ta ostatnia miejscowość ma niezwykle ciekawą historię, gdyż erekcji parafii i beneficjum kościelnego

\footnotetext{
${ }^{35}$ Por. Arkadiusz BednarczyK, „Bożogrobcy w Przeworsku”, Niedziela 2009, nr 11:7.

${ }^{36}$ Por. NiESIECKI, Herbarz Polski, 33.
} 
następowało w etapach. Pierwszym plebanem został wyznaczony w $1413 \mathrm{r}$. jeden z braci pracujący w Przeworsku, Seweryn z Wyszogrodu. Rodzina Dreśniakiewiczów dodatkowo uposażyła fundowaną parafię w stosowną parcelę na budowę kościoła, parafia otrzymała też prawo do opłat za Msze św. odprawianie w Urzejowicach, Białobokach i Niedźwiedziej, ponadto dziesięcin dworskich z Urzejowic, cześć rocznego czynszu z karczm, okolicznych łąk i ogrodów, prawo do darmowego mielenia zboża na mąkę w młynach oraz przywilej posiadania stawu rybnego, a także wyznaczoną kwotę na utrzymanie organisty ${ }^{37}$.

Obecnie można tylko przypuszczać, że bożogrobcy dążyli od razu po 1394 r. do założenia w Przeworsku szpitala-przytułku, albowiem w 1545 r. spłonęły wszystkie dokumenty erekcyjne tej instytucji. Znane są nam tylko akty dotacyjne szpitala z lat 1460 i 1477, wystawione przez Rafała Tarnowskiego, a traktowane przez badaczy jako pierwsza fundacja. Przypomnijmy tylko, że murowany szpital, tzw. szpital wielki Świętego Ducha, z kościołem św. Michała Archanioła, umieszczono na Przedmieściu Łańcuckim, natomiast drewnianą chałupę tzw. szpitala małego zbudowano na przeciwległej rubieży na Przedmieściu Jarosławskim. Być może pierwszy przytułek przy końcu XIV wieku ulokowano gdzieś w pobliżu rynku i starej fary św. Katarzyny $^{38}$. W sumie bożogrobcy prowadzili w różnym czasie na terenie Polski około 15 szpitali, co oznacza, że dokładnie w połowie ich konwentów praktykowano misję charytatywną. Fundacji ich placówek i zarazem szpitali w Polsce dokonywano przez całe średniowiecze. Pomimo że celem miechowitów nie była wyłącznie dobroczynność, to jednak żaden z innych ówczesnych zakonów nie mógł się wykazać tak dużą liczbą prowadzonych domów szpitalnych. Tworzyły one prepozytury afiliowane do Miechowa. Prepozyt, prezentowany biskupom danej diecezji przez konwent miechowski, miał do pomocy kilku braci usługujących chorym; troszczył się zarówno o sprawy duszpasterskie, administracyjno-gospodarcze, jak i życie codzienne pensjonariuszy szpitala ${ }^{39}$. W okresie swojego największego rozwoju w XVI wieku było owych zakonnych szpitali bożogrobców aż 28, podstawowymi zaś zadaniami pierwszych szpitali zakonnych było zapewnienie schronienia i wyżywienia ubogim oraz osobom pozbawionym $\mathrm{z}$ innych powodów

\footnotetext{
${ }^{37}$ Por. Urzejowice - między mitem a historiq, red. Jadwiga Orzechowska (Urzejowice: Stowarzyszenia „Urzejowice”, 2011), 60-61.

${ }^{38}$ Tadeusz TRAJDOS, „Miechowici na ziemi przemyskiej za panowania Władysława Jagiełł”, Folia Historica Cracoviensia 4-5 (1997-1998): 27.

${ }^{39}$ Marian Surdacki, „Szpitalnictwo zakonne w średniowiecznej Polsce”, Roczniki Humanistyczne 63 (2015), z. 2: 15.
} 
(starość, nieuleczalna choroba, sieroctwo) możliwości samodzielnego życia. Szpitale zakonne nie przyjmowały nigdy trędowatych, których izolowano, umieszczając w oddzielnych ośrodkach zwanych leprozoriami ${ }^{40}$.

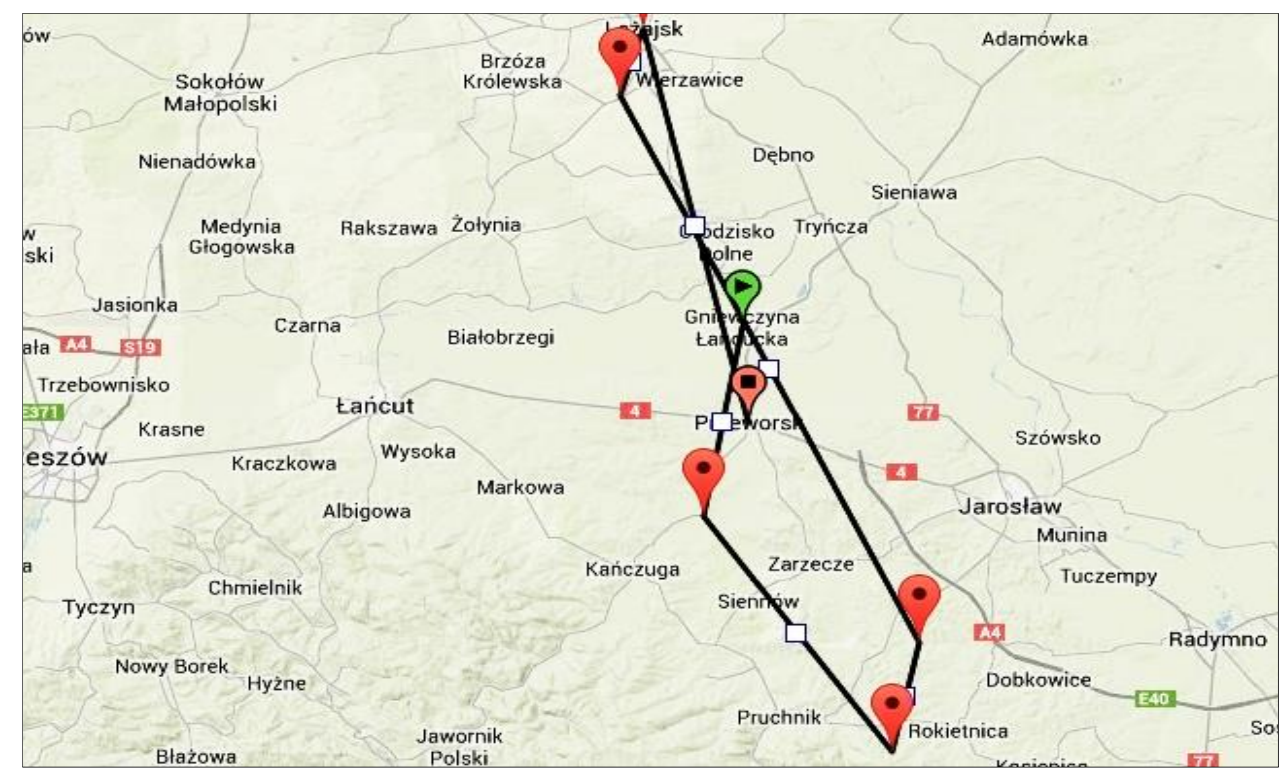

Ryc. 9. Mapa przeworskiej prowincji bożogrobców: Przeworsk, Leżajsk, Giedlarowa, Rudołowice, Tuligłowy, Urzejowice, Gniewczyn (pisownia oryginalna - dzisiaj Gniewczyna Łańcucka) (opracowanie własne na podstawie Google Maps)

Swoją obecnością na tych terenach wpisywali się również w stale rozwijającą się wówczas sieć placówek diecezjalnych i zakonnych podlegających, ze względu na rozwijanie misji na terenach Rusi Halickiej, bezpośrednio Stolicy Apostolskiej. W dokumentach archiwalnych odnajdujemy pewne reminiscencje ówczesnego zaangażowania misyjnego opactwa benedyktyńskiego z Łyśca (Świętego Krzyża) w podejmowanych przezeń akcjach politycznych na wschodzie.

Trzeba tu wspomnieć przede wszystkim, wyraźne widoczne w świetle informacji źródłowych, zainteresowanie misyjne zakonników wschodnimi sąsiadami — grekokatolikami, w tym nawet potwierdzony udział benedyktynów ze Świętego Krzyża w europejskim ruchu krucjatowym w latach 1459-1481. Ponadto w 1490 r. przeor tego klasztoru był jednym z wizy-

\footnotetext{
${ }^{40}$ Edyta BartKowiak, „Z tradycji szpitalnictwa w dawnej Polsce”, Colloquia Theologica Ottoniana" 2009, nr 1: 7.
} 
tatorów i reformatorów klasztoru bożogrobców w Przeworsku, szczególnie zaś jego placówki prowincjonalnej, klasztoru w Leżajsku, erygowanego tam po upadku pustelni św. Marii Magdaleny ${ }^{41}$.

Z leżajskimi bożogrobcami jest związana lokalna legenda, mówiąca, że urodzony w Leżajsku, w rodzinie mieszczańskiej Erazm już w młodych latach zdradzał talent do malarstwa.

Wysłany zaś do Krakowa poduczył się tam malowania do tego stopnia, że się z niego wyrobił niezgorszy artysta malarz. Po powrocie swym do Leżajska ożenił się. Obdarzony zaufaniem mieszkańców został radcą miejskim, a potem dla swego nieposzlakowanego charakteru burmistrzem leżajskim. Lecz tu nastąpił kres jego pomyślności i niezmąconego dotąd powodzenia.

Wówczas niestety spadł nań krzyż tak ciężki, że spowodował stanowczy zwrot w jego życiu. Umarła mu bowiem żona, którą miłował jak życie własne, bo mu była jasnym słonkiem w jego istnieniu. Po jej stracie stał się nieutulonym w żalu, zbrzydło mu wszystko, zaciążyły mu nawet godności miejskie, z których wnet zrezygnował, porzucił także swe artystyczne zajęcia i przestał malować, wreszcie usunął się z oczu ludzkich... i wyjechał z Leżajska. Dopiero po paru latach wrócił będąc już księdzem. Już mu siwizna - nie tylko z wieku, ile raczej z przebytych zmartwień - włosy srebrzyć poczęła, gdy ten nowy kapłan, który do zakonu Bożogrobców wstąpił, na wikarego parafialnego do Leżajska przez swą zwierzchność przysłany został.

Tutaj bardzo rychło zdobył sobie miłość ludzką, bo był istotnie kapłanem „według obrządku Melchizedeka". Pełen ducha Bożego, bardzo pobożny w modlitwie i oddany, dla usług bliźnich chętny, na ubogie szczodry i miłosierny, zyskał wkrótce opinię kapłana bardzo świątobliwego. Teraz nie oddawał się już malarstwu, czasem tylko dał się uprosić, że dla jakiegoś kościółka i to bardzo ubożuchnego wymalował obrazek Matki Bożej - innych nie malował wcale ${ }^{42}$. Właśnie do tego księdza Erazma z Leżajska udano się wówczas, by do nowego kościoła w borze leżajskim wymalował obraz Matki Bożej. Zamówienie przyjął z wielką ochotą, lecz robota szła powoli, bo się więcej przy tym obrazie namodlił, niż namalował. Już i kościół stanął w lesie gotowy, i ołtarze w nim urządzono i przybrano, a ksiądz Erazm obraz Matki Bożej dopiero wykańczał. Często też wzywał do siebie chłopca Michałka, by mu ten szczegółowo opowiedział, jak wyglądała Matka Najświętsza, którą on w tym trzykrotnym zjawieniu się w borze widywał.

\footnotetext{
${ }^{41}$ Por. Marek DeRwich, „Działalność benedyktynów łysogórskich w okresie monarchii pierwszych Jagiellonów”, Miasto i Gmina Nowa Słupia. Miasto na Królewskim Szlaku, dostęp 19.07. 2020, www.nowaslupia.pl/kategorie/sesja_pop1. Według tradycji chrześcijańskiej tamtejszy klasztor benedyktynów, dzięki św. Emerykowi, chronił i propagował kult relikwii Krzyża Świętego, był to - jak uważano - największy fragment po północnej stronie Alp. Przy okazji warto wspomnieć, że również w prawosławiu funkcjonował i funkcjonuje zakon strażników Bożego Grobu, którego jednym honorowych współbraci jest współcześnie obecny Prezydent Federacji Rosyjskiej.

${ }^{42}$ Por. Czesław Bogdalski, Pamiętnik kościoła i klasztoru OO. Bernardynów w Leżajsku spisany ze starych aktów i kronik (Kraków: Zakon OO. Bernardynów, 1929), 5-7.
} 
Michałek opowiadał chętnie, lecz za zdziwieniem, a widocznie Bożym zrządzeniem obraz wypadł całkiem inaczej. Nie przedstawił ksiądz Erazm Matki Najświętszej w towarzystwie św. Józefa, jak się zawsze ukazywała, lecz przedstawił ją z Dzieciątkiem Jezus na ręku. Tutaj oblicze Matki Najświętszej jaśniało niewypowiedzianym urokiem. Tyle na nim było tkliwej dobroci, słodyczy ujmującej, anielskiego wdzięku i wyrazistego dla ludzi współczucia, że kto tylko na ten obraz spojrzał... uginał kolana i z jakąś głębszą i serdeczniejszą się modlił ufnością. Jednym słowem... obraz ten był przepiękny ${ }^{43}$.

Niezwykle interesujący historycznie dla dziejów bożogrobców w prowincji ruskiej był $\mathrm{z}$ pewnością okres drugiej połowy XVI wieku, kiedy w Przeworsku pracował Tyburcyusz Jaskłowski, szlachetnego urodzenia, herbu Radwan, w Akademii Krakowskiej w naukach wykształcony.

Skoro w klasztorze miechowskim wykonał śluby zakonne, przełożony generalny widząc, że Tyburcyusz żarliwie prawił kazania w miechowskim kościele, posłał go do Przeworska, by tam w całej potędze prawdy, głosił słowo Boże w coraz liczniejszej parafii przeworskiej. Po śmierci ks. Winiarskiego, zostawszy proboszczem w Przeworsku, zajął się z całym poświęceniem pracą około powiększenia chwały bożej w rozległej parafii swego kościoła. Zwiedzał on to mrowisko ludu wiejskiego w chatkach i miejskich ubogich domkach; chorującym wieśniakom udzielał wsparcie; religijną pociechą pokrzepiał ich w niemocy; a ubogich mieszkańców Przeworska odzieżą i żywnością obdarzał ${ }^{44}$.

Ksiądz Jaskłowski od najmłodszych lat wiódł bogobojne życie zakonne, a że w przeworskim klasztorze wielkiej pracy dawał dowody, zgromadzenie miechowskie mianowało go przełożonym klasztoru św. Jana w Gnieźnie, i zarazem obrało go prowincjałem w Wielkopolsce należących do tego zakonu kościołów.

Przeworska kanonia miała szczęście do wybitnych przedstawicieli bożogrobców, gdyż kilkadziesiąt lat później służbę duszpasterską oraz opiekę nad szpitalem sprawował tutaj Samuel Nakielski (1584-1652). Podczas rocznej próby życia zakonnego w tutejszym klasztorze poważną rozmową, skromnym obyczajem i pobożnością zagrzewał drugich nowicjuszów do wiernego pełnienia obowiązków swego powołania. Gdy już złożył śluby uroczyste, przełożony posłał go do Gniezna dla udzielenia mu święceń kapłańskich. W 1613 r. Nakielski wrócił do Miechowa, ale niedługo tu zabawiwszy, wyjechał do Przeworska, by tam ogłaszał ludowi słowo Boże w rozległej parafii przeworskiej.

\footnotetext{
${ }^{43}$ Ibid., 8-9.

${ }^{44}$ Por. PĘKALSKI, O początku, rozkrzewianiu i upadku Zakonu, 37.
} 


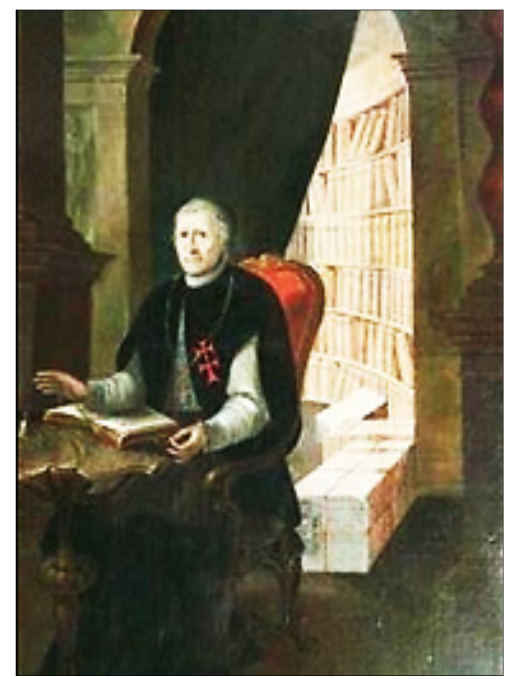

Ryc. 10. Samuel Andrzej Nakielski. Bazylika w Miechowie (za: http://bozogrobcy.miechow.info)

Wszakże, jak uważano, wyższa jego nauka, z pobożnością skojarzona, nie mogła długo taić się w Przeworsku - konwent miechowski wezwał go do swojego klasztoru i powierzył mu urząd kustosza i prowincjała, a w $1616 \mathrm{r}$. mianował go rektorem w kolegium św. Jadwigi na Stradomiu koło Krakowa. Objąwszy zarząd tegoż klasztoru, Nakielski z zapałem zajął się od razu jego sprawami i wszystko - jak pisze kronikarz — szykownie urządzat ${ }^{45}$. „Realizując zadania zgodnie z Regułą swojego zakonu, nakazującą im opiekę nad ubogimi i chorymi poprzez zakładanie szpitali-przytułków oraz sprawowania opieki medycznej i socjalnej nad ubogimi, chorymi i starcami z miasta i okolic" 46 .

Przyjmuje się, że zakon bożogrobców przetrwał w Europie do krwawych zdarzeń Rewolucji Francuskiej (1789 r.), w Polsce zaś przeważnie do początku XIX wieku. Ostatni proboszcz spośród zakonników bożogrobców w Przeworsku zmarł w 1846 r. $^{47}$

Jako szczerzy i oddani propagatorzy kultu Grobu Chrystusa mieli bożogrobcy w okresie przedtrydenckim własną liturgię zwaną jerozolimską lub

\footnotetext{
${ }^{45}$ Ibid., 150.

${ }^{46}$ Por. Krzysztof MożDżAn, „Zarys dziejów opieki zdrowotnej i społecznej na Ziemi Przeworskiej do 1945 roku". Przeworskie Zapiski Historyczne (red. Władysław Dziedzic) 2 (1995): 146-147.

${ }^{47}$ Por. PęcKowski, „Bożogrobcy. W Polsce”, kol. 881; PęKALSKI, O początku, rozkrzewianiu i upadku Zakonu, 36; Status Ecclesiae Parochialis Prevorscensis tituli Sancti Spiritus anno 1755 conscriptus et anno 1947 denuo transcriptus, 12.
} 
rytem kościoła Grobu Chrystusa. Była to średniowieczna forma rytu rzymsko-galijskiego, przystosowana do zwyczajów jerozolimskich, a potem wzbogacona o tradycje lokalne, gdy bożogrobcy przenieśli się do Italii i innych krajów europejskich ${ }^{48}$.

Bogata tradycja liturgiczna bożogrobców stała się przedmiotem licznych studiów i opracowan ${ }^{49}$, pośród których osobnych doczekał się kult Grobu Chrystusa i formy Jego czci w tradycji miechowitów ${ }^{50}$. Przyczynkiem do tego ostatniego zagadnienia jest też niniejsza praca, skoncentrowana między innymi na czci i tradycji Grobu Pańskiego w Przeworsku, ponieważ dotąd brak pełnych monograficznych opracowań na temat przeworskiego Sepulchrum Domini oraz związanego z nim formami kultu i tradycji. W tej części pracy zostanie przedstawiony w zarysie kult Grobu Chrystusa w Przeworsku, jak i w pozostałych kościołach należących do jednolitej prowincji ruskiej miechowitów. Będzie chodzić obrzędy i uroczystości sprawowane zarówno w czasach bożogrobców w Przeworsku, jak i po kasacie zakonu, gdy duszpasterzami parafii są księża diecezjalni, a tradycję podtrzymują lokalne stowarzyszenia. Główne treści religijne związane z Grobem Pańskim uległy od śmierci ostatniego bożogrobca w Przeworsku stopniowemu zanikowi, mimo że utrzymywały się pewne ludowe formy kultu wśród mieszkańców tutejszych parafii. Dopiero w 1968 r. kult Grobu Pańskiego został wskrzeszony i jest aktualnie stopniowo rozbudowywany.

Związek typowej dla bożogrobców budowli z liturgią i innymi formami kultu Grobu Pańskiego miał specyficzny i oryginalny charakter. O ile bowiem kaplice Grobu Pańskiego związane z kalwariami oraz pojedyncze przedstawienia Grobu nienależące do miechowitów były miejscami kultu Męki Pańskiej, to w przypadku przedstawień bożogrobców ich związek z kultem i liturgią miał głębsze podstawy. Bożogrobcy pielęgnowali kult Grobu Chry-

${ }^{48}$ Por. Henryk Piwoński, „Bożogrobcy. Liturgia”, w: Encyklopedia katolicka, t. 2 (Lublin: TN KUL 1976), kol. 881-882; Jerzy Józef Kopeć, Męka Pańska w religijnej kulturze polskiego średniowiecza. Studium nad pasyjnymi motywami i tekstami liturgicznymi. Textus et studia historiam theologiae in Polonia excultae spectantia nr 3 (Warszawa: Akademia Teologii Katolickiej, 1975), 271.

${ }^{49}$ Por. Jerzy Józef Kopé́, „Teksty oficjum Sacrosancti Sepulchri Hierosolymitani u bożogrobców miechowskich i w Proprium Poloniae”, Archiwa, Biblioteki i Muzea Kościelne 20 (1970): 179-194; Henryk Piwoński, „Liturgia wielkoczwartkowa u bożogrobców”. Archiwa, Biblioteki i Muzea Kościelne 35 (1977): 215-230; TENŻE, „Liturgia wielkopiątkowa u bożogrobców”, Archiwa, Biblioteki i Muzea Kościelne 43 (1981): 269-280; TENŻE, „Liturgia wielkosobotnia u bożogrobców", Studia Theologica Catholica 2 (1971): 131-146.

${ }^{50}$ Por. Józef GACKI, „Bożogrobcy”, Przegląd Religijno-Moralny 24 (1853): 109-149 oraz 221256; Jerzy Józef Kopeć, „Bożogrobcy z Miechowa - Heroldowie Pańskiego Zmartwychwstania”, Kielecki Przegląd Diecezjalny 48 (1973): 30-36. 
stusa, kładąc przy tym szczególny akcent na Zmartwychwstanie Pańskie, choć nie pomijali także wątków pasyjnych. Znajdowało to swój wyraz w obchodach Triduum Paschalnego, a także niedzieli Grobu Pańskiego i samego uroczystego wspomnienia Grobu i Zmartwychwstania w ostatnią niedzielę roku liturgicznego.

Grób Chrystusa stanowił, co już niejednokrotnie podkreślano, centrum kultu i pobożności bożogrobców. W czasie pobytu tego zakonu w Ziemi Świętej miejscem i obiektem tego kultu był oczywiście sam Grób Jerozolimski. Po klęsce wypraw krzyżowych i opuszczeniu Ziemi Świętej bożogrobcy utracili więc obiekt i miejsce, w którym mogliby czcić tajemnicę Zmartwychwstania Pańskiego. Zaczęli więc w miejscach swego pobytu wznosić kopie Grobu Jerozolimskiego. Taką budowla powstała także pod koniec XVII wieku w Przeworsku.

Budowę kaplicy Grobu Pańskiego rozpoczęto w 1697 r. Prepozytem konwentu przeworskiego bożogrobców był wówczas Franciszek Chodowicz. W kolejnych latach wygląd kaplicy Grobu, a w pewnej mierze kopii samego Grobu Chrystusa ulegał zmianom.

Z opisu kaplicy z 1755 r. $^{51}$ dowiadujemy się, że kaplica przylegała do lewej nawy kościoła. W centrum kaplicy znajdował się Grób Pański, wyposażony wewnątrz $\mathrm{w}$ mensę ołtarzową — jak czytamy w opisie — „dotąd nie konsekrowaną". Grób składał się z dwóch części. Pierwsza to część to tzw. Kaplica Anioła, druga zaś właściwa „komora grobowa”, gdzie znajdowała się wspomniana mensa ołtarzowa. Tylną ścianę Grobu stanowił wielobok podzielony ślepymi arkadami wspartymi na kolumienkach. Płaski dach wieńczyło drewniane tempietto o sześciu kolumnowych arkadach dźwigających kopułkę ${ }^{52}$.

W kaplicy przy bocznych ścianach znajdowały się dwa ołtarze: z prawej strony ołtarz Zdjęcia Pana Jezusa z Krzyża, z lewej zaś ołtarz Nawiedzenia Grobu przez św. Marię Magdalenę. Na sklepieniu kaplicy były namalowane różne przedstawienia Grobu Chrystusowego. Na centralnej ścianie znajdował się obraz Chrystusa Zmartwychwstałego.

W kronice parafialnej znajdujemy wzmiankę świadczącą o dokonujących się zmianach w wystroju kaplicy: „W kaplicy tej [...] stały dwa ołtarze. W jednym widniał obraz św. Jana Nepomucena, w drugim św. Jakuba, obydwa z 1765 r." ${ }^{53}$

\footnotetext{
${ }^{51}$ Por. Status Ecclesiae Parochialis Przevorscensis, 12.

${ }^{52}$ Por. ŁoziŃSkI, „Miechowskie Sepulchrum Domini”, 160.

${ }^{53}$ Por. Roman Penc, Kronika Parafialna w Przeworsku, mps, 107.
} 
O tych zmianach świadczy również obecny wygląd Grobu i mieszczącej go kaplicy. Obecnie Grób jest pozbawiony wspomnianego tempietto oraz dachu nad „komorą grobową”. W ścianę Grobu jest wkomponowany złoty relikwiarz w kształcie krzyża jerozolimskiego, który zawiera kamień z Grobu Chrystusa w Jerozolimie. Jeszcze większym zmianom uległ wystrój kaplicy. Do jej wnętrza wiodą odrzwia z czarnego marmuru, na których znajduje się napis z proroctwa Izajasza: „Et erit sepulchrum eius gloriosum” („I będzie grób jego sławny”, Iz 11,10). Kaplica ma wymiary: $13 \mathrm{~m}$ długości, $12 \mathrm{~m}$ szerokości, $27 \mathrm{~m}$ wysokości, licząc do szczytu wieńczącej kaplicę kopuły. Ściany kaplicy są blichowane, tzn. tynkowane gipsem z bogatą dekoracją stiukową, którą wykonał Fryderyk Bauman (1764-1840), przeworszczanin związany z rodzinami Lubomirskich i Czartoryskich. Pracował on także na dworze króla Stanisława Augusta Poniatowskiego ${ }^{54}$. Na osi arkady wejściowej przeworskiej kaplicy widnieje płaskorzeźba orła $\mathrm{z}$ rozpostartymi skrzydłami i z przerzuconą girlandą. Na końcach tej girlandy widnieją dwie tarcze herbowe - herby rodowe rodzin książęcych Lubomirskich i Czartoryskich. Przy bocznych ścianach umieszczone są dwa ołtarze: z lewej strony ołtarz Chrystusa Ukrzyżowanego z XVII wieku, z prawej — ołtarz Matki Bożej Pani Przeworskiej z XVIII wieku. Na ścianach przy wejściu do kaplicy wiszą dwa obrazy z XVI wieku: Zdjęcie z Krzyża i Złożenie do Grobu. $\mathrm{Na}$ ścianie frontowej znajduje się polichromia z 1820 r., pędzla miejscowego artysty, przedstawiająca Zmartwychwstałego Chrystusa. Stanowi ona piękne tło dla Grobu Chrystusa i podkreśla wymowę teologiczną Grobu jako miejsca cudu Zmartwychwstania. Polichromia została odkryta spod warstwy tynku podczas renowacji kaplicy w $1968 \mathrm{r}^{55}$

Porównując Grób przeworski z innymi budowlami tego typu wzniesionymi przez bożogrobców, choćby na przykład z Sepulchrum Domini w Miechowie, dostrzeżemy wiele różnic architektonicznych. Wynikają one $\mathrm{z}$ faktu, że owe budowle, a więc np. Groby w Przeworsku i w Miechowie, pochodzą $\mathrm{z}$ różnych epok i odzwierciedlają stan Grobu Jerozolimskiego z różnych okresów Jego dziejów. Przyjmując, że wzór dla przeworskiego Grobu stanowił relikwiarz kardynała Batorego, można przypuszczać, że podobnie jak relikwiarz, tak i tutejsza budowla odzwierciedla stan architektoniczny Grobu

\footnotetext{
${ }^{54}$ Por. Bożenna Majewska-Maszkowska, „Fryderyk Bauman”, w: Stownik artystów polskich i obcych w Polsce działających: malarze, rzeźbiarze, graficy, red. Danuta Pecold, Irena Rząśnicka, t. 1 (Wrocław: Zakład Narodowy im Ossolińskich, 1971), 106-107.

${ }^{55}$ Wspomniana renowacja, dokonana $\mathrm{z}$ inicjatywy ówczesnego proboszcza Bazyliki mniejszej w Przeworsku, ks. prałata Adama Ablewicza, ponownie przywróciła kaplicę Bożego Grobu do dawnej świetności.
} 
Jerozolimskiego po renowacji franciszkańskiej, czyli z drugiej połowy XVI wieku. Monument grobowy z Miechowa jest natomiast, jak uważają znawcy, wzorowany na Grobie w kaplicy Rucellai przy kościele św. Pankracego we Florencji, który miał być zgodny był $\mathrm{z}$ domniemanym wyglądem Grobu Pańskiego w Jerozolimie za czasów Konstantyna Wielkiego ${ }^{56}$.

$\mathrm{Na}$ podstawie powyższych danych można więc przypuszczać, że bożogrobcom nie chodziło o to, by w swoich sanktuariach umieszczać jak najwierniejsze kopie Grobu Jerozolimskiego, to było dla nich mniej istotne. Sprawą rozstrzygającą był fakt posiadania miejsca, gdzie można by sprawować kult Grobu Pańskiego. Monumenty architektoniczne budowane przez bożogrobców w symboliczny sposób uobecniały Grób Chrystusa jako obiekt kultu. Świadectwem tego stanu są liturgiczne formy nabożeństw ku czci Grobu, jakie upowszechniali kanonicy miechowscy.

\section{LITURGIA ZAKONU BOŻOGROBCÓW}

Zwyczaj budowania Bożych Grobów związany jest z liturgią Wielkiego Piątku, a konkretnie z obrzędem, który jest pamiątką złożenia Ciała Pana Jezusa do Grobu. Owa tradycja pochodzi z Europy Zachodniej. Pierwsza informacja o tzw. pogrzebie Chrystusa pochodzi z X wieku, opisująca jak to biskup Augsburga Ulryk (zm. 973 r.) przenosił Hostię z tamtejszego kościoła pw. św. Jana Chrzciciela do kościoła pw. św. Ambrożego, składał Ją w specjalnie przygotowanym miejscu i nakrywał kamieniem. W poranek wielkanocny odnosił Najświętszy Sakrament z powrotem do kościoła św. Jana Chrzciciela ${ }^{57}$. Od XI wieku wzrasta liczba przekazów piśmiennych, dotyczących konstruowania Bożych Grobów. Dotyczą one takich krajów, jak: Anglia, Francja, Włochy, Austria, Czechy, Węgry i Polska ${ }^{58}$. Z przykrością trzeba niestety stwierdzić, że obecnie zwyczaj budowania Grobów wielkopiątkowych na Zachodzie Europy niemal zanika, szczytnym wyjątkiem jest Hiszpania, natomiast w Polsce owa tradycja przeżywa nawet chyba swój rozkwit, podkreślając lokalną ciągłość kulturową.

\footnotetext{
${ }^{56}$ Por. ŁozIŃSKI, „Miechowskie Sepulchrum Domini”, 160-161.

57 Por. Wacław ScHENK, „Rok liturgiczny”, w: Wprowadzenie do liturgii, red. Franciszek Blachnicki, Wacław Schenk i Rudolf Zielasko (Poznań: Księgarnia Św. Wojciecha, 1967), 456; Józef MichalaK, Zarys liturgiki (Płock: Instytut Wyższej Kultury Religijnej, 1939), 204.

${ }^{58}$ Por. Zdzisław GorcZEwSKI, „Boży Grób”, w: Encyklopedia katolicka (Lublin: TN KUL, 1976), kol. 883.
} 
W ciągu wieków konstrukcje Bożego Grobu przybierały różne formy. Początkowo budowano je na ołtarzu - były to skrzynie grobowe, osłonięte zasłonami ułożonymi na kształt namiotu lub cyborium. Dolne krawędzie zasłon przyciskano kamieniami. Kamienie przy „wejściu” były opatrzone pieczęciami. W symbolice średniowiecza, którą sformułował mistrz Alkuin, grobem był sam ołtarz. Czasem Boży Grób przybierał postać tumby grobowej w kształcie skrzyni, drewnianego lub marmurowego mauzoleum albo nawet osobnej kaplicy. Od XVI wieku budowano Boże Groby o pięknych i wyszukanych kształtach. W XIX i XX wieku dekoracje Grobów Bożych budowanych $\mathrm{w}$ Polsce często miały wydźwięk symboliczny, podkreślano elementy narodowe i patriotyczne. Różnorodne formy Bożych Grobów możemy spotkać w naszym kraju także współcześnie.

W średniowieczu istniały dwa warianty pogrzebu Chrystusa. W pierwszym wariancie, stosowanym w Niemczech, składano do Grobu Najświętszy Sakrament. Wariant drugi, stosowany w Anglii i we Francji, przewidywał składanie do Grobu krzyża. W Polsce przyjął się początkowo drugi wariant, a od XVI wieku połączono obie formy, składając w Grobie zarówno krzyż, jak i Najświętszy Sakrament w korporale (Mszat krakowski z 1515 r. i Mszat płocki z 1520 r.). Według zapisów Agendy Powodowskiego z 1591 r. z biegiem czasu zaniechano zanoszenia krzyża do Grobu, wystawiano natomiast uroczyście Najświętszy Sakrament, krzyż natomiast kładziono na dywaniku, gdzie wierni przy nawiedzaniu Grobu ze czcią go całowali. Hostię składano do Grobu w korporale, kielichu, puszce lub - jak przyjęte jest też obecnie - w monstrancji nakrytej białym welonem. Adoracja w Bożym Grobie trwała od Wielkiego Piątku aż do poranka wielkanocnego, kiedy to ma miejsce Procesja Rezurekcyjna, rozpoczynająca się od Grobu Bożego.

$\mathrm{Na}$ przestrzeni wieków formy liturgiczne i nabożeństwa związane z Bożym Grobem, a zwłaszcza procesje rezurekcyjne, miały zróżnicowaną strukturę i formę. Od XVI wieku obrzędy te ulegały ujednoliceniu i takie ustalone obrzędy możemy odnaleźć w Rytuale piotrkowskim z $1631 \mathrm{r}^{59}$

W kształtowaniu się zwyczaju budowania Bożych Grobów w Europie mieli więc swój wyraźny udział bożogrobcy. Należy jednak stanowczo stwierdzić, że w świetle genezy zwyczaju budowania Bożych Grobów nie jest prawdą, jakoby stawianie, ozdabianie i nawiedzanie Bożych Grobów jest osobliwym zwyczajem bożogrobców, którzy „roznieśli [ten zwyczaj] po wszystkich krajach katolickich z Jerozolimy" ${ }^{\prime 00}$. Temu twierdzeniu przeczy

\footnotetext{
${ }^{59}$ Por. SchenK, „Rok liturgiczny”, 451-458; MichalaK, Zarys liturgiki, 205-206 i 216-218.

${ }^{60}$ Por. PęKALSKI, Piotr. O początku, rozkrzewianiu i upadku, 43; GACKI, „Bożogrobcy”, 253.
} 
fakt, że bożogrobcy powstali prawie dwa wieki później, aniżeli pojawiły się pierwsze wzmianki (już w X wieku) o zwyczaju budowania Bożych Grobów w Europie i związanych z nimi obrzędach. Mimo to nie ulega wątpliwości, że bożogrobcy poprzez szerzenie kultu Grobu Chrystusowego nadawali szersze uzasadnienie teologiczne także zwyczajowi budowania Bożych Grobów w kościołach. Groby Pańskie natomiast budowane przez samych bożogrobców, takie jak w Miechowie, Nysie czy Przeworsku, były same w sobie czymś więcej niż tylko Grobami wielkopiątkowymi, budowanymi okolicznościowo, z racji Triduum Paschalnego, w kościołach. Budowle bożogrobców, nierzadko będące wiernymi kopiami Grobu Jerozolimskiego, stawały się miejscem i niejako obiektem całorocznego kultu, ponieważ mniej lub bardziej udatnie uobecniały swój pierwowzór.

Grób Pański w Przeworsku był i jest zatem nie tylko zabytkiem architektury, ale także obiektem i miejscem żywego kultu religijnego. Na przestrzeni prawie trzech wieków istnienia przeworskiego Sepulchrum Domini spotykamy jednak różne formy kultu Grobu Pańskiego, i to zarówno w postaci kultu liturgicznego, jak i paraliturgicznego, dlatego warto omówić je dokładniej.

W Wielką Środę po Mszy św. gasi się świece na ołtarzach, w Wielki Czwartek zaś dźwięczny głos dzwonów zostaje zastąpiony głuchym łoskotem drewnianych kołatek. Kościoły zamieniają się w domy żałoby, nadchodzi Dzień męki i śmierci Chrystusa.

Po celebracji liturgicznej Wielkiego Piątku ma miejsce obrzęd pogrzebu, czyli złożenia Chrystusa do grobu. Jak wspomniano, w średniowiecznej Europie znane były dwie formy odtwarzania owego pogrzebu. Pierwsza, stosowana w głównie w krajach niemieckich, polegała na składaniu w Grobie Najświętszego Sakramentu, natomiast drugą formę, znaną i powszechnie stosowaną w Anglii i we Francji, stanowiło złożenie do Grobu krucyfiksu. W Polsce stosowano zwykle tę drugą formę albo łączono w obrzędzie obydwie formy ${ }^{61}$.

Praktykę łączenia obydwu form utrwalił Rytuat piotrkowski z 1631 r. Istnieje zapewne pewien problem, jaką formę pogrzebu Chrystusa stosowali bożogrobcy. W starych rękopisach tego zakonu brak precyzyjnych informacji na ten temat. Ksiądz Henryk Piwoński w swoim opracowaniu o liturgii wielkopiątkowej u bożogrobców podaje jednak opis pogrzebu Jezusa zawarty w ceremoniale Wielkiego Piątku u bożogrobców z Tourhout w Belgii. Przebieg owego pogrzebu wyglądał tam następująco. Celebrans, ubrany

\footnotetext{
${ }^{61}$ GACKI, „Bożogrobcy”, 275.
} 
w czarną kapę przynosił na ołtarz relikwie Krzyża św. Po ich okadzeniu następowało procesjonalne przeniesienie relikwii Krzyża do Grobu. W procesji, na której czele niesiono krucyfiks i świece, brało udział duchowieństwo zakonne oraz wierni. Wszyscy nieśli zapalone świece. Po złożeniu relikwii w Grobie, celebrans okadzał je, po czym nastepowała całonocna adoracja. Podczas adoracji można było wykonywać hymn Vexilla regis oraz werset „W pokoju jest miejsce Jego odpoczynku” z odpowiedzią ludu „I na Syjonie Jego mieszkanie". Celebrans powracał z asystą do zakrystii. W Wielką Sobotę przenoszono relikwie do Grobu modo privato. W czasie adoracji Grób był przez cały czas oświetlony ${ }^{62}$.

Pozostaje jednak kwestia, jak rzeczywiście wyglądał pogrzeb Jezusa w liturgii bożogrobców w Polsce. Można przypuszczać, że kanonicy Grobu Chrystusowego praktykowali wyżej wymienione formy pogrzebu znane i stosowane w naszym kraju, a więc złożenie do Grobu wyłącznie krzyża lub złożenie również Sanctissimum. Opracowania dotyczące bożogrobców zawierają wzmiankę, że w konwencie miechowskim „czterech kanoników zwykło odprawiać u Grobu Pańskiego czuwanie od rana Wielkiego Piątku do południa w Wielką Sobotę" ${ }^{\text {"63 }}$. Byłoby to potwierdzenie, że chodzi tu o typową adorację Najświętszego Sakramentu w Grobie Pańskim.

Do oryginalnych obrzędów wielkopiątkowych Stróżów Grobu Jerozolimskiego można zaliczyć modlitwy przed rozpoczęciem oficjum nocnego oraz adorację krzyża związaną ze śpiewem jutrzni. Nie miały one jednak bezpośredniego związku z Grobem Chrystusa ${ }^{64}$. Z przedstawionego zarysu liturgii wielkopiątkowej o bożogrobców można wyprowadzić wniosek, że chociaż centrum tej liturgii stanowi Krzyż i Męka Jezusa, to nie jest ona jednak pozbawiona pewnych nawet bezpośrednich odniesień do Grobu Pańskiego.

Wydaje się, że wielkopiątkowa celebracja ma w Grobie Jezusa jak gdyby swój finał. Świadczy o tym ceremoniał pogrzebu, a także czuwanie kanoników przy Grobie od wielkopiątkowego poranka. Tak więc Grób Chrystusa, jakkolwiek nie stanowi głównego centrum celebracji wielkopiątkowej, to można powiedzieć, że stanowi jej cel.

Podczas tej celebracji wyznaczono czytania z Księgi Wyjścia 12,1-11 - ta perykopa zawiera opis uczty baranka paschalnego, który jest typem Chrystusa i Jego zbawczej męki. Po czytaniu śpiewano responsorium „Wybaw mnie, Panie od złego człowieka" (Ps 139,2-10.14), które opisuje wewnętrzne

\footnotetext{
${ }^{62}$ Ibid., 276.

${ }^{63}$ Por. ibid., 253.

${ }^{64}$ Por. PIwoŃSKI, „Liturgia wielkopiątkowa u bożogrobców”, 276.
} 
cierpienia Chrystusa związane z Jego Męką i Śmiercią. Następnie diakon odczytywał opis Męki Pańskiej według św. Jana. Po Liturgii Słowa miały miejsce tak zwane modlitwy uroczyste (orationes solemnes). Niestety nie znamy rodzaju i liczby tych modlitw u bożogrobców ${ }^{65}$.

Trzecią częścią liturgii wielkopiątkowej była adoracja Krzyża. Oto diakon i subdiakon lub dwaj kanonicy, ubrani w czerwone kapy, przynosili osłonięty krzyż i śpiewali improperium „Ludu, mój Ludu” oparte na tekstach biblijnych (Mich 6,3-4; Pwt 8,2-3; Iz 5,4; Jr 2,21; Ps 68,22). Dwaj inni kanonicy, którzy stali obok lewego rogu ołtarza, śpiewali Trishagion („Święty Boże”), na przemian w języku greckim i łacińskim. Ów śpiew, oparty na tekście z Księgi Izajasza $(6,4)$, był używany na Bliskim Wschodzie już od V wieku (400-450 r.), natomiast w VII-VIII wieku przeszedł do liturgii galijskiej, a stamtąd do liturgii rzymskiej ${ }^{66}$.

Wielka Sobota to dzień spoczynku Ciała Pana Jezusa w Grobie, a jednocześnie wieczorna wigilia Zmartwychwstania Pańskiego. Bożogrobcy obchodzili ten dzień zgodnie ze swoją uroczystą tradycją, o czym informują nas ich liczne kodeksy liturgiczne ${ }^{67}$. Liturgia Wielkiej Soboty składała się z trzech części: Liturgii światła, Liturgii chrztu św. oraz Liturgii mszalnej.

Liturgia światła rozpoczynała się od czytań. Jest to dwanaście czytań, którym towarzyszą modlitwy i śpiewy, zgodnie z liturgią rzymską z okresu przed Soborem Watykańskim II ${ }^{68}$. Oryginalnym obrzędem liturgii Wigilii Paschalnej u bożogrobców było oczekiwanie na przyjście „świętego ognia”. Opis tego obrzędu znajdujemy w kodeksach liturgicznych bożogrobców ${ }^{69}$.

Trzy lub cztery osoby udawały się do miejsca, gdzie był umieszczony krzyż, tam nakazywano im oczyszczenie się z grzechów w sakramencie pokuty. Następnie udawały się one boso do Grobu w asyście służby liturgicznej niosącej kandelabry i kadzielnice. Jedna z osób niosła krzyż. Okrążali Grób trzy lub cztery razy. Jedna z osób, wchodząc do grobu, klękała i pochylała głowę. Wszyscy oczekiwali na zstąpienie „cudownego ognia”. Gdy czasami to nie następowało, wtedy obchodzono Grób jeszcze sześcio- lub

\footnotetext{
${ }^{65}$ Por. PIwoŃSKI, „Liturgia wielkopiątkowa u bożogrobców”, 272.

${ }^{66}$ Por. ibid.

${ }^{67}$ Por. Biblioteca Vaticana, sygn. 659, Codex Latinus Barberinik, 1160; Biblioteka Seminarium Duchownego w Kielcach, sygn. RI-8, Antyfonarz miechowski 1562-1563; Biblioteka Uniwersytetu Wrocławskiego, sygn. IQ 175, Ordo divini officii Conventus Crucigerorum cum duplici rubro cruce $X I V w$; Biblioteka Uniwersytetu Wrocławskiego, sygn. IF 386, Graduat bożogrobców z Nysy.

${ }^{68}$ Por. Piwoński, „Liturgia wielkosobotnia u bożogrobców”, 136.

${ }^{69}$ Por. Codex Latinus Barberini i Ordo divini officii; PIwoŃski, „Liturgia wielkosobotnia u bożogrobców", 136-137.
} 
siedmiokrotnie, modląc się przy tym hałaśliwie. Na koniec niosący krzyż wchodził z innymi do Grobu. Gdy „znajdywano” ogień, zapalano od niego paschał, celebrans zaś intonował hymn Ciebie Boga, wystawiamy.

Ten dziwny zwyczaj „poszukiwania ognia” niektórzy pisarze nazywali „pobożnym podstępem”70. Patriarcha jerozolimski Fulcheriusz (1146-1157), wiedząc o rzekomości tego „cudu”, nakazał poświęcać ogień. Zwyczaj ten, pomimo zakazu Stolicy Apostolskiej już z 1268 r., był praktykowany na przykład przez bożogrobców na Śląsku ${ }^{71}$. Nie ulega jednak wątpliwości fakt, że przeworskie Sepulchrum Domini nigdy nie było świadkiem tego ,pobożnego podstępu". Na pół godziny przed uroczystościami podpalano ułożone obok krzyża, na zewnątrz kościoła, ognisko z choinek bożonarodzeniowych, a następnie od tego ognia odpalano paschał i kadzidła oraz świece niesione przez wiernych.

Wielkosobotnia liturgia chrztu św. obejmowała procesję do chrzcielnicy, poświęcenie wody chrzcielnej i sam obrzęd chrztu. Podczas tego obrzędu chór śpiewał krótszą wersję Litanii do Wszystkich Świętych ${ }^{72}$.

Liturgia Wielkiej Soboty u bożogrobców była pośrednio związana z Grobem Chrystusa przez uczczenie tajemnicy Zmartwychwstania, będącej osią i centrum tej liturgii. Związek materialny liturgii Wigilii Paschalnej z Grobem ujawniał się w obrzędzie oczekiwania na „święty ogień”, bo ten obrzęd odbywał się właśnie w Grobie Pańskim. Grób Pana Jezusa zajmuje więc w liturgii wielkosobotniej ważne, choć już nie pierwszoplanowe miejsce.

Niedziela Zmartwychwstania Pańskiego, będąca największym świętem chrześcijaństwa, miała u bożogrobców bogatą oprawę liturgiczną. Oprócz obrzędów typowych dla ówczesnej liturgii Zmartwychwstania Pańskiego spotykamy w liturgii bożogrobców wiele obrzędów oryginalnych, niekiedy wręcz unikatowych. Oryginalność tej celebracji polegała między innymi na ścisłym związku z Grobem Chrystusa.

Liturgii niedzieli Zmartwychwstania Pańskiego rozpoczynała się od procesji rezurekcyjnej. Opis tej procesji znajduje się w Agendzie miechowskiej z $1576 \mathrm{rr}^{73}$, umieszcza procesję rezurekcyjną przed matutinum. Inne

\footnotetext{
${ }^{70}$ Por. PIWOŃSKI, „Liturgia wielkosobotnia u bożogrobców”, 137.

${ }^{71}$ Por. Zdzisław OBERTYŃski, „Ślad tzw. św. ognia jerozolimskiego w liturgii śląskiej”, Sprawozdania Towarzystwa Naukowego Warszawskiego. Wydziat II Nauk Spolecznych i Filozoficznych, Warszawa 1938, s.31-35; PIWOŃski, „Liturgia wielkosobotnia u bożogrobców”, 144-145.

${ }^{72}$ PIwoŃSKI, „Liturgia wielkosobotnia u bożogrobców”, 138.

${ }^{73}$ Por. Biblioteka Seminarium Duchownego w Kielcach, Agenda miechowska 1576, k. 76-78; Henryk Piwoński, „Liturgia wielkanocna u bożogrobców miechowskich”, Roczniki TeologicznoKanoniczne 16 (1969), z. 4: 94-95.
} 
rękopisy bożogrobców przyjmują, że miała miejsce między matutinum a laudesami ${ }^{74}$.

Procesja rezurekcyjna rozpoczynała się w Grobie. Celebrans i inni kapłani wraz z asystą klękali wokół Grobu i śpiewali antyfonę "Chwała Tobie, Trójco Święta”. Potem odmawiano formułę „Panie zmiłuj się nad nami”, Modlitwę Pańską i Pozdrowienie Anielskie. Następnie celebrans śpiewał wezwanie „Zmartwychwstaniem Twoim, Chryste. Alleluja”. Lud wierny zaś odpowiadał: „Niebo i ziemia niechaj się radują. Alleluja”.

W celebracji Mszy św. niedzieli Zmartwychwstania Pańskiego nie brak więc istotnych wątków nawiązujących właśnie do Grobu jako właściwego miejsca Zmartwychwstania.

Myśl związaną z Grobem Pańskim podejmowali w tym dniu bożogrobcy w dramatyzacji Nawiedzenia Grobu. Jakkolwiek praktyka takich dramatyzacji liturgicznych była powszechnie znana w średniowiecznej Europie, to jednak obrzęd sprawowany przez bożogrobców odznaczał się na tle tamtych dramatyzacji oryginalnością. Opis tego obrzędu znajdujemy w rękopisach zakonnych ${ }^{75}$.

Dodatkowa tradycja Nawiedzenia Grobu miała miejsce po zakończeniu śpiewu ostatniego responsorium jutrzni. Wtedy to trzej klerycy, przebrani za niewiasty, przybywali do Grobu, poprzedzani przez asystę niosącą światło i kadzidło. Klerycy nieśli złote lub srebrne naczyńka, w których znajdowała się odrobina oleju. Śpiewali trzykrotnie antyfonę „Deus qui revolvet”. Przy wejściu do Grobu stali dwaj inni klerycy przebrani za „Aniołów”. Mieli oni zasłony na głowach, a w rękach trzymali zapalone świece. Zapytywali „niewiasty”, które przybyłe do Grobu: „Kogo szukacie?”. One zaś odpowiadały: „Jezusa Nazarejczyka”. „Aniołowie” odpowiadali: „Nie ma Go tu. Zmartwychwstał”. „Niewiasty” wchodziły do Grobu na krótką modlitwę. Następnie śpiewano hymn Ciebie Boga wystawiamy oraz werset: „Zmartwychwstaniem Twoim, Panie. Alleluja” z odpowiedzią ludu: „Niebo i ziemia się radują. Alleluja”.

Zapiski z Codex Latinus Barberini, z którego pochodzi przedstawiony opis, zawierają klauzulę stwierdzającą, że już w XIV wieku ten zwyczaj nie był praktykowany z powodu braku miejsca ${ }^{76}$. Pozwala to przypuszczać, że Grób Pański w Przeworsku, pochodzący z XVII wieku, nie był już świadkiem tych obrzędów.

\footnotetext{
${ }^{74}$ Por. Codex Latinum Barberini; Ordo divini officii; zob. PIWoŃSKI, „Liturgia wielkanocna u bożogrobców miechowskich", 97.

${ }^{75}$ Por. Codex Latinus Barberini, k. 75-76; Ordo divini officii, k. 45; PIwoŃski, „Liturgia wielkanocna u bożogrobców miechowskich”, 99-100; Zenon MoDZELEWSKI, „Estetyka średniowiecznego dramatu liturgicznego", Roczniki Humanistyczne 12 (1964), z. 1: 5-7.

${ }^{76}$ Por. PIwoŃsKI, „Liturgia wielkanocna u bożogrobców miechowskich”, 100.
} 
Rękopisy bożogrobców zawierają opis procesji do Grobu po prymie ${ }^{77}$. Kanonicy gromadzili się w Grobie, miała miejsce adoracja, podczas której śpiewano między innymi werset „Witaj dniu świąteczny”. Następnie rozpoczynała się procesja, w której obchodzono świątynię jeden raz. Gdy wchodzono do kościoła, kantor intonował antyfonę "Chrystus powstał z martwych”, a następnie antyfonę „Mówią teraz Żydzi”. Później celebrans śpiewał modlitwę poprzedzoną wersetem „Zmartwychwstał Pan z Tego Grobu”. W modlitwie zwracał się do Boga, który w dniu Zmartwychwstania Swojego Syna otworzył nam bramy wieczności, aby wysłuchał ludzkie prośby, które im poddaje swą świętą łaską. Procesję kończyły śpiewy Witaj dniu świąteczny lub Ja jestem Alfa i Omega.

Henryk Piwoński w swoim opracowaniu o liturgii wielkanocnej bożogrobców miechowskich wspomina jednak, że „Wielka księga choralna” z Miechowa nic nie mówi o takiej procesji ${ }^{78}$. Można zatem uznać, że procesji do Bożego Grobu po Prymie nie było też w przeworskim Sepulchrum Domini.

Przedstawiony zarys wielkanocnej liturgii bożogrobców jasno ukazuje jej związek z Grobem Chrystusa. Należy jednak pamiętać, że przedstawione obrzędy pochodzą z okresu przed Soborem Trydenckim, natomiast Grób Chrystusa w Przeworsku powstał już w okresie potrydenckim. Możemy jednak przypuszczać, że ze względu na zakonny charakter liturgii miechowitów, jakieś formy owych obrzędów musiały mieć miejsce także w przeworskiej kaplicy Grobu Pańskiego.

Cechą duchowości bożogrobców jest stałe ukierunkowanie na tajemnicę paschalną, a zwłaszcza na Zmartwychwstanie, toteż także poza Triduum Paschalnym spotykamy w ciągu roku kościelnego obchody, które w swej treści nawiązują do tej najważniejszej tajemnicy wiary chrześcijańskiej. Głównym momentem nawiązania u bożogrobców do tajemnicy Zmartwychwstania Chrystusa było święto, a nawet uroczystość Grobu Pańskiego, obchodzona w drugą niedzielę po Wielkanocy, i było to, jak odnotowuje jeden z historyków zakonu, święto tytularne bożogrobców ${ }^{79}$.

Warto wszelako wspomnieć o tradycjach liturgicznych, w których termin obchodu święta Grobu Pańskiego był trochę inny. Oto w kościele św. Marii Magdaleny we Wrocławiu obchodzono to święto we wtorek po Niedzieli Białej. W opactwie w Cambrais we Francji celebrowano je w oktawie Bożego

\footnotetext{
${ }^{77}$ Por. Codex Latinus Barberini, k. 76; Ordo divini officii, k. 46; PIwoński, „Liturgia wielkanocna u bożogrobców miechowskich", 101-102.

${ }^{78}$ Por. PIwOŃSKI, „Liturgia wielkanocna u bożogrobców miechowskich”, 102.

${ }^{79}$ Por. PĘKALSKI, O początku, rozkrzewianiu i upadku Zakonu, 43-44.
} 
Ciała, w innych zaś regionach Francji zwykle w dniu 15 lipca. Ten ostatni termin był datą upamiętniającą kolejną rocznicę zdobycia Jerozolimy przez krzyżowców w 1099 r. $^{80}$

Teksty liturgiczne bożogrobców przeznaczone na święto Grobu Pańskiego powstały prawdopodobnie w XIV wieku. Obejmowały formularz mszalny i oficjum brewiarzowe ${ }^{81}$. Pierwotna wersja oficjum na święto Grobu Pańskiego, zaczynająca się od słów Quam dulcis haec solemnitas (pierwsza antyfona Nieszporów), znajduje się w Antyfonarzu miechowskim z $1562 \mathrm{r}^{82}$ Owo oficjum było wielokrotnie wydawane, miedzy innymi przez znanego już nam ks. Samuela Nakielskiego. Służyło ono zakonowi niemal do połowy XVIII wieku. Wydano także, wzorowane na tym oficjum, tzw. officium parvum, czyli małe oficjum ${ }^{83}$. Owo oficjum, wydane w Krakowie w 1664 r. w języku łacińskim, odmawiali z pobożności prywatnej sami bożogrobcy, a także co światlejsi i bardziej wykształceni członkowie Bractwa Grobu Chrystusa.

Od połowy XVIII wieku Kanonicy Grobu Pańskiego zaczęli używać nowego oficjum Exaltate Dominum Deum nostrum. 1 grudnia 1742 r., uwzględniając prośbę prokuratora generalnego bożogrobców, Kongregacja Obrzędów zaaprobowała nowe oficjum, a 5 lutego 1744 r. włączyła je do Proprium festorum Regni Poloniae ${ }^{84}$. Odmawiało go zatem także duchowieństwo rzymskokatolickie w całej Polsce. Rok później prepozyt miechowski Jakub Radliński poprosił Kongregację o zatwierdzenie doboru czytań I i II nokturnu i taką aprobatę otrzyma ${ }^{85}$. W $1751 \mathrm{r}$. nowe oficjum ukazało się drukiem w Rzymie. Te wszystkie zabiegi były związane z pragnieniem skupienia pod władzą przełożonego polskich bożogrobców wszystkich bożogrobskich domów zakonnych w Europie ${ }^{86}$. Jakuba Radlińskiego uważa się za autora tego oficjum. W XIX wieku tekstu oficjum bożogrobców o Grobie Chrystusa zaczęły używać zgromadzenia zakonne pasjonistów i redem-

\footnotetext{
${ }^{80}$ Por. Kopeć, Męka Pańska, 292.

${ }^{81}$ Ibid., s. 272-289.

${ }^{82}$ Por. KoPEĆ, „Teksty oficjum”, 182.

${ }^{83}$ Por. Officium parvum Sanctissimi Sepulchri. Pro usu confraternitatis tituli eiusdem, in ecclesiis Canonicorum regularium SS. Sepulchri Domini Hierosolymitani pridem erectae (Cracoviae: b.w., 1664); por. Venceslaus [Wacław] Muratowicz, Gloria Sacrosancti Hierosolymitani Sepulchri Domini (Varsoviae et Lipsiae [Warszawa, Lipsk]: Apud B. Heinsii heredes, 1775), 789-806.

${ }^{84}$ Por. Jakub RadLiński, Synopsis nonnullorum Privilegiorum, Decretorum, Indulgentiarum et aliquarum Praerogativarum Ordinis Canonicorum et Canonissarum Regularium Custodum Sacrosancti Hierosolymitani Sepulchri Christi Domini (Cracoviae [Kraków]: Typis Michaelis Josephi Antonii Dyaszewski, 1764), 16-19.

${ }^{85}$ Ibid, s. 17.

${ }^{86}$ Por. KoPÉ́, Męka Pańska, 277.
} 
ptorystów, których duchowość jest skupiona wokół tajemnicy paschalnej Chrystusa $^{87}$.

$\mathrm{Z}$ historią oficjum brewiarzowego wiąże się historia formularza mszalnego o Grobie Pańskim. Nie mamy oryginalnych tekstów tego formularza. Natrafiono tylko na pewne ślady ich istnienia. Samuel Nakielski, powołując się na bliżej nieznane Missale Cracoviense, podaje, że święto Grobu Pańskiego znane było wcześniej w diecezji krakowskiej. Inny zakonnik bożogrobca, Wacław Muratowicz, wzmiankuje o istnieniu formularza mszalnego o Grobie Chrystusa w mszale biskupa krakowskiego Piotra Tomickiego, wydanym $\mathrm{w}$ Wenecji $\mathrm{w} 1532 \mathrm{r}^{88} \mathrm{~W}$ odtworzeniu formularza mszalnego bożogrobców pomocne są również dwa kodeksy liturgiczne: piętnastowieczny mszał z kościoła św. Marii Magdaleny we Wrocławiu, a przede wszystkim zawarty w nim tzw. drugi formularz Mszy o Grobie Pańskim, oraz wspomniany już Graduat bożogrobców z Nysy, pochodzący z XIV wieku ${ }^{89}$. W każdym razie 1 grudnia 1742 r. Kongregacja Obrzędów Stolicy Apostolskiej zatwierdziła, wraz z nowym oficjum brewiarzowym, także nowy formularz Mszy św. o Grobie Chrystusa. Dwa lata później włączono go wraz $\mathrm{z}$ oficjum do Proprium Poloniae ${ }^{90}$. Ten formularz jest obecny do dzisiaj w Mszale rzymskim tacińsko-polskim, umieszczony w „Dodatku dla Kościołów partykularnych"91.

Na uwagę zasługuje fakt, że w konwencie przeworskim uroczyste oficjum o Grobie Chrystusa było odmawiane w czasie popołudniowego wystawienia Najświętszego Sakramentu również w każdą niedzielę Wielkiego Postu ${ }^{92}$.

Znacznie mniej wiemy obecnie o formularzu mszalnym na niedzielę Grobu Pańskiego. Brak jest bowiem starszej wersji tegoż formularza. W jednym z opracowań, dotyczących między innymi liturgii bożogrobców i kultu Grobu, podjęta została próba jego odtworzenia. Za podstawę kompilacji posłużyły autorom dwa, wspomniane już, kodeksy liturgiczne: Mszał z kościoła św. Marii Magdaleny we Wrocławiu i Gradual Bożogrobców z Nysy. Tutaj zaprezentowany został jedynie pewien szkic tego formularza, gdyż dokładne jego przedstawienie jest przedmiotem wspomnianego opracowania ${ }^{93}$,

\footnotetext{
${ }^{87}$ Por. Kopeć, „Teksty oficjum”, 180-187.

${ }^{88}$ Por. Samuel NAKIELSKI, Officia propria festorum Ordinis Cannonicorum SS. Sepulchri Domini Hierosolymitani ad normam Breviarum Romanum redacta (Kraków: b.w., 1620), 6; MuRATOWICZ, Gloria Sacrosancti, 787; KoPEć, „Teksty oficjum”, 191.

${ }^{89}$ Por. Kopeć, Męka Pańska, 279.

${ }^{90}$ Por. RAdLIŃSKi, Synopsis nonnulorum Privilegiorum, 16-19.

${ }^{91}$ Por. Mszat Rzymski łacińsko-polski (Paryż: Éditions du Dialogue, 1968), 177-178.

${ }^{92}$ Por. Status Ecclesiae Parochialis Przevorscensis, 165-166.

${ }^{93}$ Por. Kopé́, Męka Pańska, 278-279.
} 
a poza tym szczegółowe omawianie form kultu naruszałoby ramy tematyczne niniejszego artykułu, wszelako materiał ten jest niezmiernie ważny dla całościowego spojrzenia na tematykę Grobu Chrystusa w Przeworsku. Ograniczenie się do przedstawienia kwestii przeworskiego Sepulchrum Domini tylko w aspekcie zagadnień architektonicznych znacznie zubażałoby wiedzę na temat roli i znaczenia budowli.

Krzewicielem kultu Grobu Pańskiego, obok zakonników bożogrobców, było w Przeworsku także Bractwo Grobu Chrystusowego, założone w 1659 r. W tymże roku papież Aleksander VII nadał członkom tego bractwa odpusty, a biskup przemyski Stanisław Sarnowski pozwolił te odpusty ogłosić ${ }^{94}$. Głównym celem i zadaniem członków konfraterni Grobu Pańskiego było rozpamiętywanie tajemnicy Męki Jezusa Chrystusa, a zwłaszcza złożenia do Grobu Jego Ciała. Mieli oni obowiązek spowiedzi w każdą ostatnią niedzielę miesiąca. Spowiedź ta była możliwa dopiero po uzyskaniu odpustu zupełnego. W każdy piątek odprawiane było nabożeństwo za zmarłych członków bractwa. We wszystkie niedziele, począwszy od Wielkanocy aż do ostatniej niedzieli roku kościelnego, członkowie uczestniczyli we Mszy św. wotywnej o Zmartwychwstaniu Pańskim. Odprawiali też comiesięczną procesję do Grobu Pańskiego. Mieli też obowiązek odmawiania w domu lub w kościele „Godzinek o Grobie Chrystusa”, a w każdą niedzielę Wielkiego Postu po południu „przy Grobie wielkopiątkowym odbywając czterdziestogodzinne nabożeństwo, ze świecami klęczeli" 95 .

Członkowie bractwa mieli do dyspozycji napisany przez ks. Jakuba Radlińskiego specjalny modlitewnik ${ }^{96}$, który zawierał m.in. wspomniane „Godzinki o Grobie” oraz triennę i koronkę o Grobie Chrystusa. „Godzinki o Grobie Pańskim” są ułożone na wzór „Godzinek o Niepokalanym Poczęciu Najświętszej Maryi Panny”. Treść hymnów na poszczególne godziny koncentruje się wokół tajemnicy Śmierci, Złożenia do Grobu i Zmartwychwstania Chrystusa oraz wydarzeń z tymi tajemnicami związanych. Bogactwo

\footnotetext{
${ }^{94}$ Por. Hieronim Eugeniusz WyCZAwSKI, „Katalog Archiwum Prowincji OO Bernardynów w Krakowie", Archiwa Biblioteki i Muzea Kościelne 3 (1961), z. 1-2: 62.

${ }^{95}$ Por. GACKI, „Bożogrobcy”, 250-251; Por. Archiwum Parafialne w Przeworsku, Jan WACŁAwski, Kronika parafialna, t. 5, s. 111, 226 (mps); Antoni Podleś, „Dzieje czterdziestogodzinnego nabożeństwa w Polsce", w: Studia z dziejów liturgii w Polsce, red. Wacław Schenk, t. 4 (Lublin: TN KUL, 1982), 259; Krystyna KuźMAK, „Bractwo kościelne”, w: Encyklopedia katolicka, t. 2 (Lublin: TN KUL, 1986), kol. 1017.

${ }^{96}$ Jakub RadLiŃSKI, Ogłos tryumfalny Grobu Chrystusowego o skatę tegoż Grobu obijający się albo Godzinki, Tryenna, y Koronka o Grobie Chrystusowym Bractwu tegoż Grobu Chrystusowego, i owszem wszystkim wiernym dla pożytku duchownego (Lublin: Drukarnia Collegium Societatis Jesu, 1730).
} 
treści pozostaje w związku ze wspomnieniem Paschy Chrystusa, która stanowi centralne wydarzenie zbawcze. Trienna zawiera rozważania o Grobie Chrystusa, związane $\mathrm{z}$ trzema dniami poświęconymi Jego tajemnicy. Koronka o Grobie Pańskim składa się z pięciu tajemnic: Złożenie z Krzyża, Namaszczenie Przenajświętszego Ciała Pana Jezusa, Straż przy Grobie, Zstąpienie do piekieł i Zmartwychwstanie. Przy każdej tajemnicy, oprócz modlitw „Ojcze nasz”, „Zdrowaś Maryjo” i „Chwała Ojcu”, odmawiano też antyfonę opartą na tekście biblijnym nawiązującym swą treścią do danej tajemnicy.

Działalność bractwa Grobu Chrystusowego przyczyniała się niewątpliwie do wzbogacenia form kultu Grobu Pańskiego w kościele w Przeworsku, a wspomniany modlitewnik ks. Radlińskiego jest świadectwem troski bożogrobców, by cześć i kult Grobu Chrystusowego rozwijała się wśród wiernych gromadzących się w ich kościołach i klasztorach.

\section{WSPÓŁCZESNE FORMY KULTU BOŻEGO GROBU}

Na koniec trzeba by wspomnieć o współczesnych formach kultu Grobu Pańskiego w Przeworsku. Porównanie obecnych form kultu z formami praktykowanymi onegdaj przez bożogrobców i bractwo Grobu dokładniej naświetli historyczno-społeczną perspektywę rozwoju kultu Grobu Pańskiego w przeworskim sanktuarium.

Obrzędy związane z Bożym Grobem zostały znacznie wzbogacone zwłaszcza w okresie baroku w wyniku działalności wspomnianych bractw Grobu Chrystusowego. Jak wynika z zapisków o coraz liczniejszych podróżnych, którzy od XVII wieku odwiedzali interesujące miejsca na ziemiach polskich, goście byli m.in. zdumieni pomysłowością, przepychem i wystawnością Bożych Grobów. W okresie zaborów liczniejsze były elementy symboliki narodowej" ${ }^{97}$.

Współcześnie przyjęła się i wciąż jest praktykowana adoracja i czuwanie przy Bożym Grobie zwłaszcza młodzieży (głównie męskiej, ale coraz częściej również żeńskiej) w obecności warty grobowej pełnionej przez „Turków” czy „Strażaków"98. W 1846 r., po śmierci ostatniego przeworskiego bożogrobcy, ówczesnego proboszcza, Kaspra Mizerskiego, i po przejęciu duszpasterstwa w parafii przez księży diecezjalnych kult Grobu Chrystusa został zredukowany do pobożności prywatnej, niewielkiej aktywności stowarzyszeń, a sam monument grobowy podupadał wyraźnie zaniedbany.

\footnotetext{
${ }^{97}$ Por. Renata Hryń-Kú́miereK, Rok Polski - zwyczaje i obrzędy (Poznań: Publicat, 1998), 39.

${ }^{98}$ Por. GoRCZEWSKI, „Boży Grób”, kol. 883-884.
} 


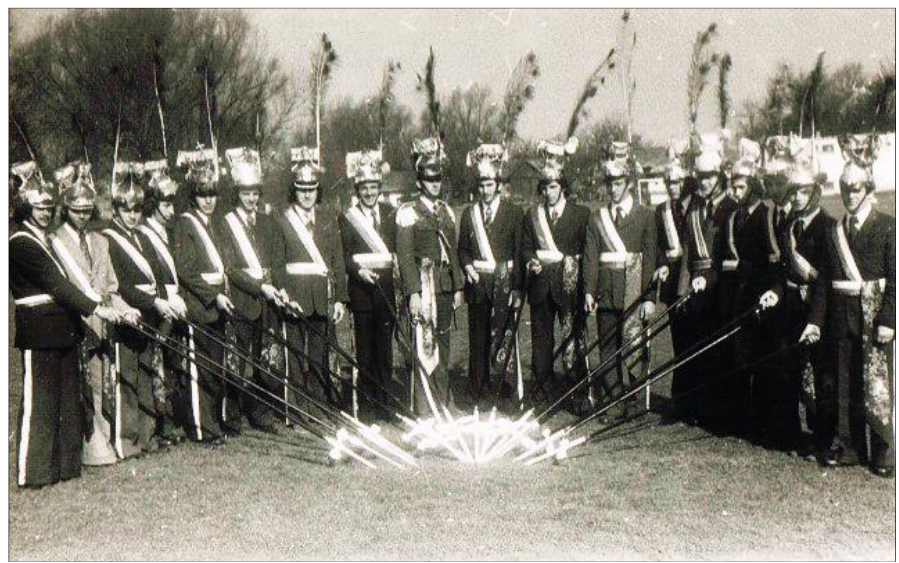

Ryc. 11. „Turki” — Straż Grobowa. Mirocin 1974 r. (zbiory własne)

Gruntowną renowację przeworskiego Sepulchrum Domini przeprowadzono dopiero pod koniec lat sześćdziesiątych XX wieku. Jej inicjatorem był ks. prałat Adam Ablewicz, ówczesny proboszcz przeworskiej parafii. Celem tej renowacji było nie tylko przywrócenie wartości architektonicznej samej budowli, ale też właściwej rangi kultowi Grobu Chrystusa.

Następnym krokiem było przywrócenie oficjalnych obchodów niedzieli Grobu Pańskiego - 20 kwietnia 1969 r. parafia Przeworsk obchodziła po raz pierwszy od stu kilkudziesięciu lat święto Chrystusowego Grobu. Po całodziennej adoracji Najświętszego Sakramentu w kaplicy Grobu Jerozolimskiego odbyła się procesja rezurekcyjna, prowadzona przez bpa Ignacego Tokarczuka, ordynariusza przemyskiego. Po procesji ordynariusz odprawił pontyfikalną Mszę św. W kazaniu określił Grób Chrystusa jako miejsce, które uczy każdego człowieka dobrze żyć i dobrze umierać, aby mieć udział w chwale Zmartwychwstania. Służbę liturgiczną - lektorów i ministrantów - podczas tych tradycyjnych obrzędów Wielkanocnych przygotował i prowadził według odnowionego ceremoniału ks. Antoni Wawrzyszko ${ }^{99}$.

Doceniając wyjątkowy charakter przeworskiej fary, ks. prałat Adam Ablewicz rozpoczął trwające wiele lat i kosztujące wiele trudu remonty i renowacje kompleksu dawnego klasztoru bożogrobców (ołtarze, ograny, plebania). Równocześnie, z zaangażowaniem i głęboką pobożnością, pełnił funkcję duchowego przewodnika miejscowej wspólnoty katolickiej, od 1975 r. także jako prałat Kapituły Jarosławskiej. Przyczynił się do utworzenia nowych świątyń w dekanacie przeworskim: w Dębowie, w Studzianie i w Grzęsce. Utwo-

\footnotetext{
${ }^{99}$ Por. Kronika Diecezji Przemyskiej 3 (1969): 82.
} 
rzył punkt katechetyczny w Przeworsku i koordynował tam nauczanie religii w czasach, kiedy było ono zakazane w szkołach. W sposób szczególny przyczynił się zwłaszcza do rekonstrukcji i rozpowszechnienia tradycji sanktuarium Grobu Chrystusa w Przeworsku, poprzez renowację wiernej kopii Kaplicy Grobowej z Jerozolimy i wznowienia Misterium Wielkanocnego ${ }^{100}$.

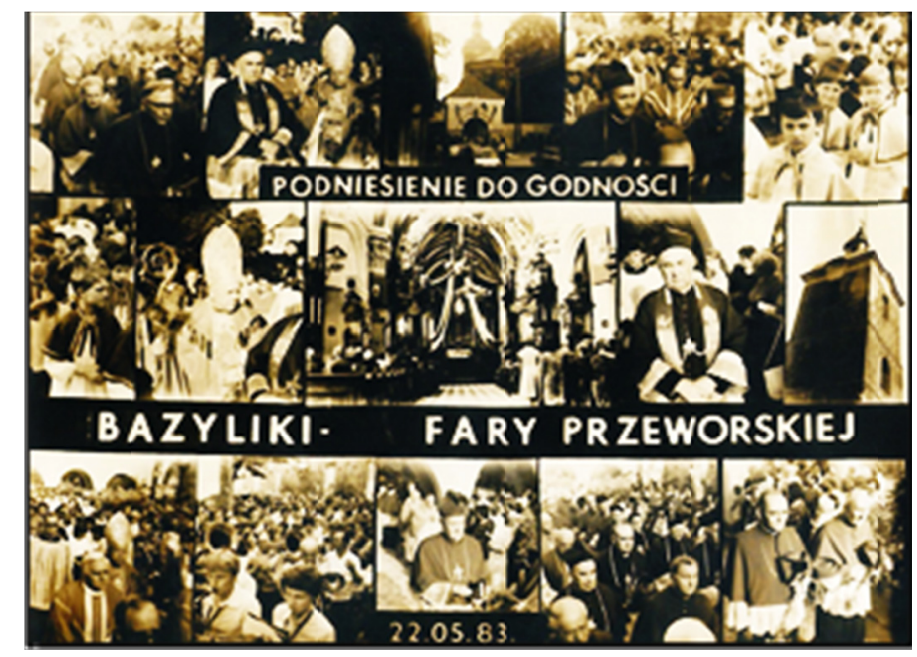

Ryc. 12. Pamiątkowe portfolio fotografii z uroczystości podniesienia do godności Bazyliki Mniejszej fary w Przeworsku, 22 maja 1983 r. (zbiory własne)

Jego działania przyczyniły się do nadania przez papieża Jana Pawła II w 1982 r. przeworskiemu kościołowi farnemu rangi Bazyliki Mniejszej. Dowód uznania spotkał go także od władz państwowych PRL, w $1984 \mathrm{r}$. otrzymał bowiem nagrodę Ministra Kultury i Sztuki „Dla najlepszego użytkownika obiektu zabytkowego". Jako ostatni pracę ks. Adama Ablewicza nagrodzili mieszkańcy Przeworska, przyznając mu Nagrodę Ratusz '97. Dwa lata później w dniu jego pogrzebu osobiste telegramy z kondolencjami przesłali papież Jan Paweł II i abp Józef Życiński, metropolita lubelski.

Współcześnie szczególnie istotne znaczenie dla kontynuowania tradycji średniowiecznych bractw Bożego Grobu mają w pewnym sensie zorganizowane grupy młodych mężczyzn, a ostatnio także kobiet, tworzących „Warty grobowe” - „Turki”. W Przeworsku i okolicach są widoczni zwłaszcza w okresie Wielkiego Tygodnia.

\footnotetext{
${ }^{100}$ Por. Adam ABLEwicz, ,, Kościół parafialny pw. Św. Ducha, niegdyś prepozytura Bożogrobców Miechowskich w Przeworsku”. Przeworskie Zapiski Historyczne (red. Władysław Dziedzic) 2 (1995): 105-130.
} 


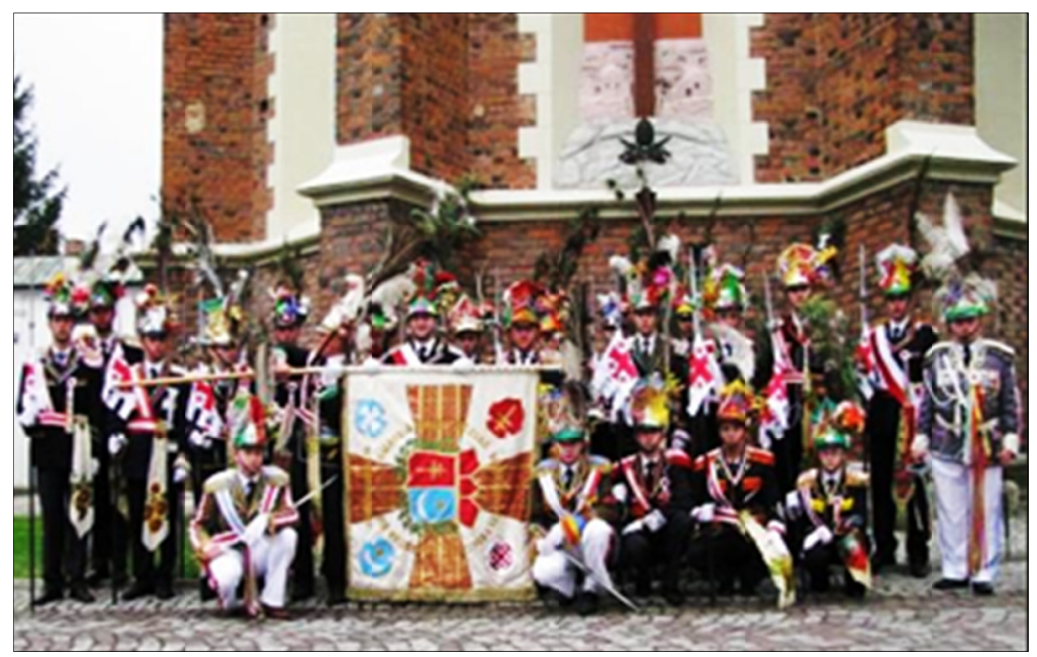

Ryc. 13. Członkowie Stowarzyszenia Straży Grobu Bożego „Gwardia” w Przeworsku (zbiory własne)

Zwykle wczesnym rankiem w Wielką Niedzielę lub jeszcze w poprzedzającą noc w niektórych wsiach „Turki” „budzą wiernych na rezurekcję” biciem w werbel (wieś Nowosielce), strzelaniem z bani, czyli z metalowej bańki na mleko, z puszek przy użyciu karbidu, z hyzli, tzn. rodzaju działa wykonanego domowym sposobem $\mathrm{z}$ wąskiej butli po acetylenie (to głównie w oddziałach ze wsi Mirocin i Ujezdna), z rury lub inaczej z klucza wypełnionego siarką i karbidem, a także już zupełnie nowocześnie za pomocą odpalanych petard. We wsi Dębów zwyczaj budzenia na rezurekcję bębnieniem, połączonym ze śpiewaniem pieśni wielkanocnych, został zarzucony, natomiast miejscowy oddział „Turków” strzela z działa armatnieg,o, a towarzysząca im czasami orkiestra jeszcze przed szóstą rano odgrywa melodię marszową „na pobudkę” mieszkańcom wiosek.

Pojawienie się oddziału „Turków” w pobliżu kościołów wczesnym rankiem w Niedzielę Wielkanocną zawsze wzbudza radość i ekscytację wiernych z Przeworska i okolicznych parafii. Udział w uroczystościach rozpoczynają oni od trzykrotnego paradnego przemarszu wokół kościoła. Doprawdy zachwycający i wzruszający widok stanowi odbywająca się z ich udziałem późniejsza uroczysta procesja rezurekcyjna oraz poranna Msza św. Podczas procesji pospołu ze służbą liturgiczną „Turki maszerują w strojach paradnych, bogatych w barwne obszycia i aplikacje ${ }^{101}$.

\footnotetext{
${ }^{101}$ Por. Nasze Turki - Straże grobowe w powiecie przeworskim (Przeworsk, Rzeszów: Muzeum w Przeworsku/Podkarpacka Regionalna Organizacja Turystyczna, 2012), 18.
} 
Od 1969 r. obchodzone jest w Przeworsku corocznie, tak jak w czasach bożogrobców, święto Grobu Pańskiego w II niedzielę po Wielkanocy, czyli III niedzielę Wielkanocy według obecnej nomenklatury liturgicznej. Głównymi formami obchodów są: wystawienie Najświętszego Sakramentu w Grobie Pana Jezusa po prymie i całodzienna adoracja oraz uroczysta procesja rezurekcyjna, a po niej Msza św. z procesją.

Procesja rezurekcyjna miewała i ma zwykle następujący przebieg. Najpierw celebrans wraz z asystą udają się do kaplicy Grobu, gdzie przez kilka minut adorują Chrystusa ukrytego w Najświętszym Sakramencie. W tym czasie chór wykonuje starą antyfonę „Chwała Tobie, Trójco Święta”, którą kiedyś przy tej okazji śpiewali także bożogrobcy ${ }^{102}$. Następnie po okadzeniu Najświętszego Sakramentu kapłan, biorąc monstrancję, intonuje staropolską pieśń wielkanocną Wesoly nam dziś dzień nastat. Wraz z jej śpiewem rozpoczyna się procesja wokół świątyni. W czasie jej trwania wierni śpiewają pieśni wielkanocne. Kiedy procesja wchodzi do kościoła, chór śpiewa pieśn Zmartwychwstat Pan prawdziwie. Już w kościele podczas śpiewu Przed tak wielkim Sakramentem kapłan okadza Sanctissimum. Po odśpiewaniu modlitwy „Boże, Ty w Najświętszym Sakramencie ołtarza”, następuje błogosławieństwo Najświętszym Sakramentem. Po repozycji Sanctissimum zaś rozpoczyna się uroczysta Msza św.

Podczas obchodu niedzieli Grobu Pańskiego 10 kwietnia 1988 r. we Mszy św. po procesji rezurekcyjnej po raz pierwszy posłużono się formularzem mszalnym o Grobie Chrystusa ${ }^{103}$. Wcześniej w dniu tego reaktywowanego święta korzystano z formularza Mszy św. o Zmartwychwstaniu Pańskim. We Mszy św. o Grobie Pańskim pierwsze czytanie Liturgii słowa stanowi fragment Izajaszowej czwartej pieśni o cierpiącym Słudze Jahwe (Iz 52,13-53). Psalm responsoryjny (Ps 118,16-18,19-21,22-23) jest hymnem na cześć Pana, który stał się naszym Zbawieniem. W drugim czytaniu, z Dziejów Apostolskich (Dz 13,16.26-31), zawarta jest zaś Dobra Nowina o Zmartwychwstaniu Chrystusa głoszona przez św. Pawła Żydom w Antiochii Pizydyjskiej. Przed Ewangelią jest wykonywana sekwencja wielkanocna „Niech w święto radosne paschalnej ofiary”. Perykopa ewangeliczna to Łukaszowy opis ukazania się Zmartwychwstałego Chrystusa uczniom idącym do Emaus (Łk 24,13-27).

\footnotetext{
${ }^{102}$ Por. PIwoŃSKI, „Liturgia wielkanocna u bożogrobców miechowskich”, 94-95.

${ }^{103}$ Por. Mszał Rzymski łacińsko-polski, 177-178.
} 


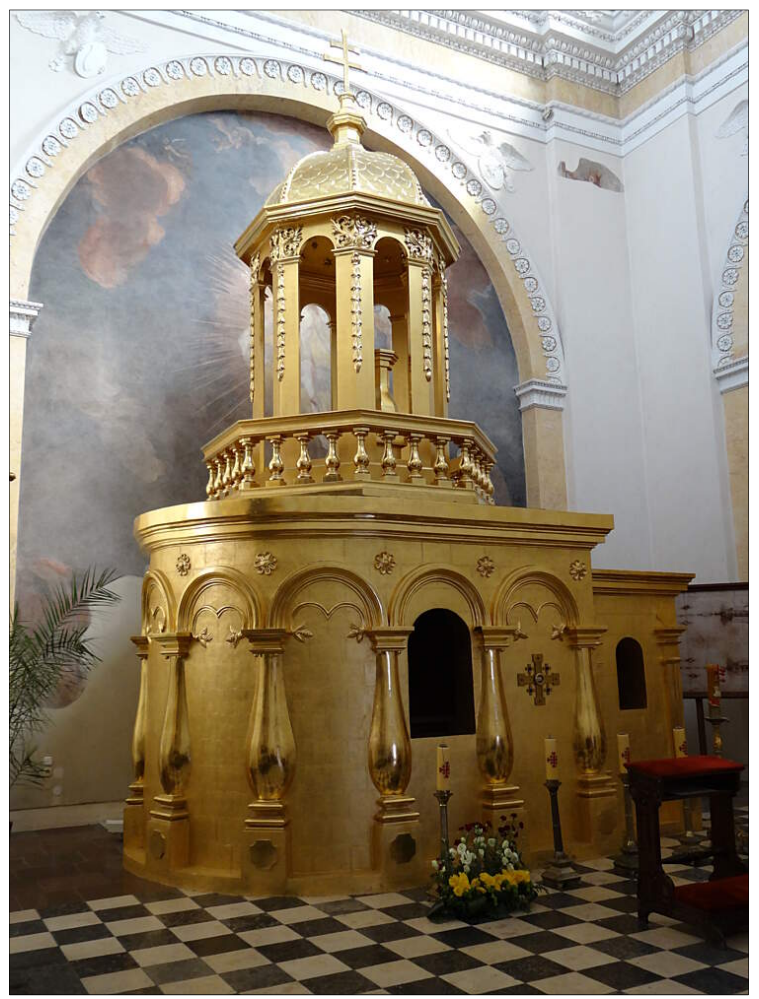

Ryc. 14. Replika Bożego Grobu w Bazylice w Przeworsku, stan obecny (za: commons.wikimedia.org/wiki, public domain)

Msza św. według formularza o Grobie Chrystusa jest odprawiana w przeworskim sanktuarium także jako Msza wotywa w piątki, w które nie przypada uroczystość, święto lub wspomnienie obowiązkowe, a także gdy pozwala na to okres roku kościelnego. Miejscem celebracji jest ołtarz wewnątrz Grobu Pańskiego. Szkoda tylko, że ta Msza św. nie jest odprawiana tak regularnie, jak można by sobie tego życzyć.

Pobożność prywatna związana z kultem Grobu Pańskiego przejawia się przede wszystkim w nawiedzaniu Grobu w czasie Triduum Paschalnego i Niedzieli Grobu Pańskiego. Wskutek zaniedbań kultu Grobu Bożego po objęciu duszpasterstwa w parafii przez księży diecezjalnych obecnie dla większości wiernych Boży Grób w Przeworsku kojarzy się tylko z powszechnym w całym polskim Kościele zwyczajem budowania Grobów wielkopiątkowych. Trzeba, aby obok ożywienia kultu Grobu Bożego, co niewątpliwie ma już miejsce, zapoznawać wiernych w Polsce z bogatą tradycją 
kultu Grobu Bożego u bożogrobców. Pozwoliłoby to na właściwe ukierunkowanie form pobożności związanej z Grobem Chrystusa. Chodzi też głównie o to, by cześć dla Grobu Bożego wśród wiernych nie ograniczała się do odmawiania modlitwy różańcowej, ale także pogłębione rozważanie tajemnicy Bożego Grobu ${ }^{104}$.

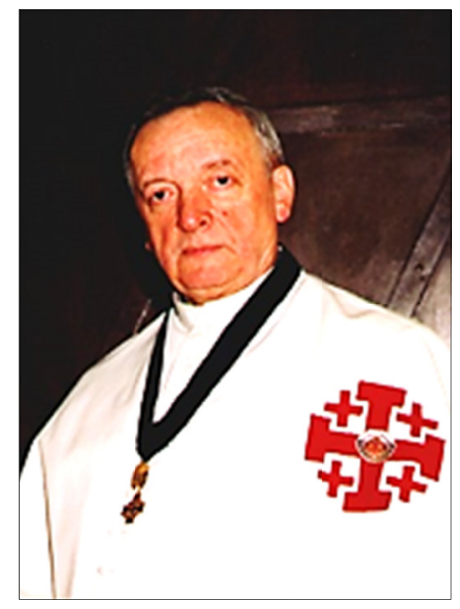

Ryc. 15. Ksiądz prałat dr Stanisław Szałankiewizz, Komandor OESSH (zbiory własne)

Nowym przejawem kultu Grobu Pańskiego w Przeworsku są coraz liczniejsze pielgrzymki. Ruch pielgrzymkowy do tutejszego sanktuarium rozpoczął się na dobre w 1983 r. po podniesieniu przez papieża Jana Pawła II przeworskiego kościoła Ducha Świętego, mieszczącego replikę Bożego Grobu, do rangi Bazyliki Mniejszej. Otwierało to większą możliwość do rozszerzenia form kultu Grobu Pańskiego o popularną wśród Polaków religijną praktykę pielgrzymowania. Obecnie wszakże kaplica Grobu Pańskiego jest traktowana przede wszystkim jako miejsce kultu Zmartwychwstania Pańskiego, co zawdzięcza staraniom ks. prałata dra Stanisława Szałankiewicza, proboszcza od 1989 do 2012 r., który na odpowiednie adaptacje i remonty pozyskał znaczące fundusze od Wojewódzkiego Konserwatora Zabytków, a jego wysiłki zostały wsparte oczywiście nie mniejszą szczodrobliwością parafian.

\footnotetext{
${ }^{104}$ Praktycznym przejawem działań w tym kierunku będzie z pewnością projektowane wydanie albumowego modlitewnika, w którym powinny się znaleźć między innymi Godzinki i Koronka o Grobie Pańskim oraz inne rozważania i modlitwy poświęcone miejscu pośmiertnego spoczynku i zmartwychwstania Chrystusa.
} 
Ostatnia renowacja kaplicy, ale także całej bazyliki pw. Ducha Świętego w Przeworsku, rozpoczęła się w 2005 r. za sprawą ks. prałata dra Stanisława Szałankiewicza, acz także ks. prałat Tadeusz Gramatyka, który od sierpnia 2012 r. przejął obowiązki proboszcza parafii Świętego Ducha w Przeworsku, kontynuuje prace renowacyjne w Bazylice i w samej kaplicy Bożego Grobu. Podczas owej renowacji m.in. odkryto polichromię w kopule kaplicy Bożego Grobu. W jej centrum są przedstawione sceny nawiązujące do czterdziestodniowej chrystofanii Jezusa, a więc okresu od Zmartwychwstania do Wniebowstąpienia. W rogach kopuły widać cztery starotestamentalne sceny: Arka Noego, Samson pokonujący lwa, Daniel w jaskini lwów i uwolnienie Jonasza z wnętrza wielkiej ryby.

W ramach renowacji dokonano zmian w ołtarzach bocznych. Obraz Matki Bożej Pani Przeworskiej przeniesiono do ołtarza bocznego w Bazylice, a Krzyż Chrystusa - na osobne miejsce w kaplicy (przy klęczniku). W ołtarzach bocznych umieszczono obrazy Złożenie do Grobu oraz Niewiasty przy Grobie.

Sam Grób Pański pokryto warstwą złota. Przywrócono także tzw. tempietto, w którego wnętrzu znajduje się tron, na którym wystawiany jest Najświętszy Sakrament w Wieki Piątek i w Niedzielę Bożego Grobu. Na początku kwietnia 2014 r. podczas Mszy św. na zakończenie rekolekcji wielkopostnych została poświęcona wierna kopia Całunu Turyńskiego, wykonana w skali 1:1 w Turynie przez prof. Aldo Guareschi, włoskiego syndonologa. Dzięki staraniom proboszcza, ks. prałata Tadeusza Gramatyki jest ona w przeworskim sanktuarium kolejnym, obok pustego Grobu Pańskiego, „niemym świadkiem męki, śmierci i zmartwychwstania Pana Jezusa”. Wciąż trwają prace renowacyjne, które przyczyniają się do odnowy i przywrócenia dawnej świetności przeworskiego sanktuarium, ale też odsłaniają też kolejne tajemnice historii tego miejsca.

Odnowienie kultu Grobu Chrystusa w kościele przeworskim jest procesem wciąż ewoluującym, choć z wyraźnie kontynuowaną tradycją. Istnieje wiele możliwości ożywienia tego kultu i ruchu religijnego zwłaszcza wśród tutejszych parafian. Jako źródeł do inspiracji kolejnych projektów należy przy tym sięgnąc do bogatej tradycji kultu Grobu Chrystusa u bożogrobców w czasach historycznych oraz adaptować zwyczaje przyjęte $\mathrm{w}$ tradycji bractw Grobu Chrystusowego. Z tą tradycją należałoby stopniowo zapoznać wiernych parafii, w tym szczególnie młodzież, a także pielgrzymów przybywających coraz częściej do sanktuarium w Przeworsku. 


\section{PODSUMOWANIE}

Idea dobroczynności, opieki nad ludźmi chorymi i potrzebującymi pomocy przepełniała intencje rycerzy, a następnie zakonników tworzących zgromadzenia krzyżowców. Jest dostrzegalna również w tradycji religijnej bożogrobców na terenie niemal całej Europy, gdyż prowadzili oni ,jedne z bardziej popularniejszych" i najbardziej licznych hospicjów publicznych, przeznaczonych głównie do udzielania doraźnej pomocy pielgrzymom podążających do Jerozolimy oraz innych sanktuariów pielgrzymkowych w Europie. W swych znaczniejszych domach klasztornych bożogrobcy organizowali też niejako pośrednie/zastępcze sanktuaria pielgrzymkowe wokół kaplic z repliką Grobu Pańskiego oraz miejsc kontemplacji, niejednokrotnie $\mathrm{z}$ autentycznymi relikwiami świętych, cieszących się niezmierną popularnością u średniowiecznych pątników, co było ważne $\mathrm{z}$ uwagi na ówczesną politykę muzułmanów w Palestynie, zwłaszcza blokadę przez nich pielgrzymek do Jerozolimy.

Przechowywane w takich kaplicach relikwie drzewa Krzyża Świętego miały papieskie prawa odpustów religijnych, zbliżonych znaczeniem do tych, które mogła zyskiwać jedynie osoba odbywająca osobistą pielgrzymkę do Bazyliki Grobu Chrystusa w Jerozolimie. Wprawdzie z uwagi na zniszczenie zasobów archiwalnych wciąż niewiele wiemy o działalności bożogrobców w pierwszych latach ich pobytu w Polsce, możemy jednak przypuszczać, że w Miechowie, położonym przy głównym trakcie handlowym z Krakowa na północ, powstało, oprócz niezwykle aktywnego ośrodka duszpastersko-charytatywnego, także hospicjum przeznaczone głównie dla osób chorych oraz pielgrzymów.

Bożogrobcy w Miechowie prawdopodobnie już w XII wieku zorganizowali po raz pierwszy społeczne ośrodki kultu religijnego skupione wokół tradycji chrześcijańskich związanych z symboliką Grobu Chrystusa, oczywiście w kontekście Zmartwychwstania. Wskazują na to zwłaszcza symboliczne wezwania nowej świątyni klasztornej, mianowicie Świętego Grobu, i szpitala - Ducha Świętego oraz udokumentowana wiarygodna społeczna tradycja religijno-kulturowa, kultywująca fakty nie bez znaczenia dla ówczesnych pierwszych chrześcijan w Polsce. Dyskusyjne jest przy tym, czy rzeczywiście szlachetny Jaksa Gryfita w 1163 r. przywiózł do Miechowa autentyczne relikwie Ziemi Świętej i kamienie z Grobu Chrystusa w Jerozolimie. Jego żona była przecież córką możnowładcy śląskiego Piotra Włostowica, z którym wspólnie skutecznie odpierali najazdy niemieckiego Albrechta Niedźwiedzia na Dolny Śląsk i tym samym jego intencjom sprzyjania na tych terenach konkurencyjnemu zakonowi rycerskiemu - joannitom. 
Z upływem lat kult miejsca Zmartwychwstania Chrystusa, którym był przecież Boży Grób, mimo że zbawcze męka i śmierć dokonały się na Krzyżu, rozprzestrzeniał się stopniowo, z optymistycznym chrześcijańskim przesłaniem zmartwychwstania wszystkich, w całej Polsce, docierając również na Podkarpacie do Przeworska. Wraz z rozwojem samego zakonu powstawały też coraz liczniejsze szpitale/schroniska dla wciąż wzrastającej liczby średniowiecznych pielgrzymów oraz codzienne przytułki dla chorej i ubogiej ludności miejscowej. One też jako pierwsze stawiały opór średniowiecznym epidemiom i jako jedyne świadczyły fachową pomoc w poważnych urazach i chorobach. Wokół zaś propagowanych przez bożogrobców idei religijnych powstały fraternie świadczące lokalnie różnoraką pomoc, w tym posługę w ostatniej drodze życia.

Obecnie celem bożogrobców w świecie jest wzmacnianie u swoich członków praktyki życia chrześcijańskiego, w absolutnej wierności papieżowi i w zgodzie z nauczaniem Kościoła, kierowanie się zasadą miłosierdzia, która przed wiekami uczyniła ten Zakon podstawowym środkiem pomocy dla chrześcijan w Ziemi Świętej. Zakonnicy popierają i wspierają dzieła i instytucje charytatywne oraz kulturalne i społeczne Kościoła katolickiego w Ziemi Świętej, zwłaszcza w Patriarchacie Łacińskim Jerozolimy, z którym bożogrobcy utrzymują tradycyjnie stałą więź. Bożogrobcy wspierają zachowanie i propagowanie wiary na ziemiach Palestyny oraz promują zainteresowanie tą pracą nie tylko wśród katolików rozsianych po całym świecie i zjednoczonych w miłości przez symbol tego zakonu, ale także wśród wszystkich innych chrześcijan.

Realnie to konieczność mocnego stania na straży praw Kościoła katolickiego w Ziemi Świętej, gdyż Zakon Rycerski Grobu Świętego w Jerozolimie w swojej obecnej postaci jest jedyną świecką instytucją Państwa Watykańskiego, której zadaniem jest zaspokajanie potrzeb Patriarchatu Łacińskiego Jerozolimy oraz wszelkich działań i inicjatyw wspierających chrześcijańską obecność w Ziemi Świętej. Składki i dary materialne wnoszone przez jej członków i sympatyków, są więc wciąż głównym źródłem finansowania instytucji patriarchalnych. Celem bożogrobców była i nadal jest pomoc chrześcijanom w Ziemi Świętej w osiągnięciu standardów edukacyjnych i zawodowych, które umożliwią im odgrywanie aktywnej roli w społeczeństwie własnego kraju na poziomie, który zapewni im równość z ludźmi innych wyznań.

Od końca XIX wieku Zakon sfinansował budowę około 40 patriarchalnych szkół w Palestynie i Jordanii, a także zobowiązał się do finansowania ich bieżących kosztów. Obecnie do tych szkół, od przedszkoli, poprzez 
szkoły podstawowe, gimnazja i szkoły ponadgimnazjalne, a także technika, uczęszcza około 19 tys. uczniów i studentów. Zaangażowanie Zakonu $\mathrm{w}$ edukację pomaga uporać się z bardzo ważnym problemem $\mathrm{w}$ tym regionie, czyli przyzwyczajeniem ludzi różnych ras i religii do życia w pokoju i wzajemnym szacunku. Jeśli owe wartości są propagowane od najmłodszych lat, mogą zostać zaszczepione w umysłach dzieci, w przeciwnym razie młodzi ludzie stają z łatwością ofiarami ekstremistycznych ideologii. Koszty bieżące Patriarchatu, m.in. pensje dla około tysiąca nauczycieli i innych pracowników placówek oświatowych, koszty seminarium patriarchalnego oraz sierocińców i klinik, a także współfinansowanie nowych przedsiębiorstw produkcyjnych i usługowych oraz inne projekty, w tym budowa mieszkań dla młodych rodzin chrześcijańskich. Owe koszty są ogromne i nieustannie rosną, stanowiąc ogromny ciężar dla Zakonu — można je udźwignąć tylko dzięki hojności aktywnych członków Zakonu.

\section{BIBLIOGRAFIA}

\section{Archiwalia}

Biblioteca Vaticana, sygn. 659, Codex Latinum Barberini; Ordo divini officii, 1160.

Biblioteka Seminarium Duchownego w Kielcach, Agenda miechowska 1576, k. 76-78.

Biblioteka Seminarium Duchownego w Kielcach, sygn. RI-8, Antyfonarz miechowski 1562-1563.

Biblioteka Uniwersytetu Wrocławskiego, sygn. IQ 175, Ordo divini officii Conventus Crucigerorum cum duplici rubro cruce, XIV wiek.

Biblioteka Uniwersytetu Wrocławskiego, sygn. IF 386, Graduał bożogrobców z Nysy.

Muratowicz, Venceslaus [Wacław]. Gloria Sacrosancti Hierosolymitani Sepulchri Domini. Varsoviae et Lipsiae [Warszawa, Lipsk]: Apud B. Heinsii heredes, 1775.

Mszat Rzymski łacińsko-polski. Paryż: Éditions du Dialogue, 1968.

NAKIElski, Samuel. Officia propria festorum Canonici Ordinis SS. Sepulchri Domini Hierosolymitani a multo quidem tempore collecta et longo usu ab ordino observata nunc vero primum [...] ad normam Breviarii Romani in ordinem redacta [...] in lucem edita. Cracoviae [Kraków]: b.w., 1620.

Penc, Roman. Kronika Parafialna, Archiwum Parafialne w Przeworsku.

RADLIŃSKI, Jakub. Ogłos tryumfalny Grobu Chrystusowego o skałę tegoż Grobu obiiaacy się albo Godzinki, Tryenna, y Koronka o Grobie Chrystusowym Bractwu tegoż Grobu Chrystusowego, y owszem wszystkim wiernym dla pożytku duchownego. Lublin: Drukarnia Collegium Societatis Jesu, 1730.

RADLIŃSKI Jakub. Synopsis nonnullorum Privilegiorum, Decretorum, Indulgentiarum et aliquarum Praerogativarum Ordinis Canonicorum et Canonissarum Regularium Custodum Sacrosancti Hierosolymitani Sepulchri Christi Domini. Cracoviae [Kraków]: Typis Michaelis Josephi Antonii Dyaszewski, 1764. 
Status Ecclesiae Parochialis Prevorscensis tituli Sancti Spiritus anno 1755 conscriptus et anno 1947 denuo transcriptus.

WACŁAwSKI, Jan. Kronika parafialna, t. 5, Archiwum Parafialne w Przeworsku.

\section{LITERATURA}

ABlewicz, Adam. „Kościół parafialny pw. Św. Ducha, niegdyś prepozytura Bożogrobców Miechowskich w Przeworsku". Przeworskie Zapiski Historyczne (red. Władysław Dziedzic), 2 (1995): 105-125.

BARCZYŃski, Włodzimierz. „Bożogrobcy Miechowscy”. Małopolski Szlak Bożogrobców. Dostęp 12 października 2020. http://bozogrobcy.miechow.info/

Bartkowiak, Edyta. „Z tradycji szpitalnictwa w dawnej Polsce”. Colloquia Theologica Ottoniana" 2009, nr 1: 103-121.

Bogdalski, Czesław. Pamiętnik kościoła i klasztoru OO. Bernardynów w Leżajsku spisany ze starych aktów i kronik. Kraków: Zakon OO. Bernardynów, 1929.

Borkowski, Aureliusz. „O Grobie Bożym (1149-1949)”. Ruch Biblijny i Liturgiczny 1 (1949), nr 3: 165-168. DOI: 10.21906/rbl.2369.

Budzyński, Zdzisław. Dzieje opieki społecznej w ziemi przemyskiej i sanockiej (XV-XVIII w.). Przemyśl, Kraków: Polskie Towarzystwo Historyczne, 1987.

ChojnACKA-DzIEsZyŃSKa, Małgorzata. „Bazylika Bożogrobców w Przeworsku pod wezwaniem Świętego Ducha”. Opoka.net.pl. Dostęp 12 października 2020. http://www.oessh.opoka.net.pl/ page.php?strona=przeworsk.

DĄ̧rowski, Eugeniusz. „Grób Chrystusa”. W: Podręczna encyklopedia biblijna, red. Eugeniusz Dąbrowski, 433-434. Poznań: Księgarnia Św. Wojciecha, 1960.

DERWICH, Marek. „Działalność benedyktynów łysogórskich w okresie monarchii pierwszych Jagiellonów”, Miasto i Gmina Nowa Słupia. Miasto na Królewskim Szlaku, dostęp 19.07.2020, www.nowaslupia.pl/kategorie/sesja_pop1.

Dudziński, Paweł. Alfabet heraldyczny. Warszawa: Diogenes, 1997.

„Equestrian Order of the Holy Sepulcher”. Latin Patriarchate of Jerusalem. Dostęp 12 października 2020. https://www.lpj.org/category-1136/equestrian-order-of-the-holy-sepulcher.html

Eteria. Pielgrzymka do miejsc świętych, przeł. Władysław Wojciech Szołdrski (Pisma Starochrześcijańskich Pisarzy [PSP] t. 6, Warszawa: ATK, 1970), 160-197.

GACKI, Józef. „Bożogrobcy”. „Przegląd Religijno-Moralny” 24 (1853): 109-149 oraz 221-256

GLiŃSKI, Efrem. „Z historii Grobu świętego”. Ruch Biblijny i Liturgiczny 1 (1948), nr 2: 64-71. DOI: $10.21906 / \mathrm{rbl} .2302$

Gloger. Zygmunt. Encyklopedja Staropolska Ilustrowana. T. 3: Kapelusz - Pieczęć, 8 (Karawaka, karawika). Warszawa: Druk P. Laskauera i S-ki, 1902.

Grand Magisterium Vatican. The Equestrian Order of the Holy Sepulchre of Jerusalem. Dostęp 12 października 2020.http:// www.oessh.va/content/ordineequestresantosepolcro/en.html.

Hrý́-Kuśmierek, Renata. Rok Polski-Zwyczaje i obrzędy. Poznań: Publicat, 1998.

Ignas, Katarzyna. Nasze Turki - Straże grobowe w powiecie przeworskim. Przeworsk, Rzeszów: Muzeum w Przeworsku Zespół Pałacowo-Parkowy/Podkarpacka Regionalna Organizacja Turystyczna, 2012.

Katalog zabytków sztuki w Polsce, red. Jerzy Szablewski. T. 1, z. 8. Warszawa: Państwowy Instytut Sztuki, 1953. 
KoŁYszKo, Marek. Wizerunki podwójnego krzyża w kulturze Polskiej. Toruń: Wydawnictwo Naukowe UMK.

Kopeć, Jerzy Józef. „Bożogrobcy z Miechowa - Heroldowie Pańskiego Zmartwychwstania”. Kielecki Przegląd Diecezjalny 48 (1973): 30-36.

Kopeć, Jerzy Józef. Droga Krzyżowa. Dzieje nabożeństwa i antologia wspótczesnych tekstów. Poznań: Księgarnia Św. Wojciecha, 1975.

Kopeć, Jerzy Józef. Męka Pańska w religijnej kulturze polskiego średniowiecza - Studium nad pasyjnymi motywami i tekstami liturgicznymi. Textus et studia historiam theologiae in Polonia excultae spectantia nr 3. Warszawa: Akademia Teologii Katolickiej, 1975.

KoPEĆ, Jerzy Józef. „Teksty oficjum Sacrosancti Sepulchri Hierosolymitani u bożogrobców miechowskich i w Proprium Poloniae”, Archiwa, Biblioteki i Muzea Kościelne 20 (1970): 179194.

KUŹMAK, Krystyna. „Bractwo kościelne”. W: Encyklopedia katolicka. T. 2, 1113-1020. Lublin: TN KUL, 1986.

KотUlA, Franciszek. Znaki przeszłości: odchodzace ślady zatrzymać w pamięci. Warszawa: Ludowa Spółdzielnia Wydawnicza, 1976.

KWAK, Jan. „Szpitale w miastach górnośląskich”, Limes 1 (2008): 20.

ŁACH, Stanisław. „Miejsce śmierci i Zmartwychwstania Chrystusa”. Ruch Biblijny i Liturgiczny 11 (1958), nr 2: 124-134. DOI: 10.21906/rbl.2655.

ŁoZIŃSKI, Jerzy. „Miechowskie Sepulchrum Domini”. Biuletyn Historii Sztuki 31 (1969): 151-165 .

MACHEJEK, Michał. „Materiały źródłowe zakonu bożogrobców w archiwach watykańskich”. W: Bożogrobcy w Polsce, red. Cyprian Wilanowski, 203-220. Miechów, Warszawa: IW PAX, 1999.

Majewska-MaszKowsKa, Bożenna, „Fryderyk Bauman”. W: Stownik artystów polskich i obcych w Polsce działajacych: malarze, rzeźbiarze, graficy, red. Danuta Pecold, Irena Rząśnicka. T. 1, 106-107. Wrocław: Zakład Narodowy im Ossolińskich, 1971.

MichalaK, Józef. Zarys liturgiki. Płock: Instytut Wyższej Kultury Religijnej, 1939.

„Miechów Bożego Grobu”, Diecezja kielecka. Dostęp 02.01.2020. http://www.diecezja.kielce.pl/ parafie/miechow-grobu-bozego

MıKA, Norbert. „Bożogrobcy raciborscy w średniowieczu”. W: Klasztor w mieście średniowiecznym i nowożytnym, red. Marek Derwich, Anna Pobóg-Lenartowicz i Krzysztof Guzikowski, 419-426. Wrocław, Opole: DiG 2000.

Modzelewski, Zenon. „Estetyka średniowiecznego dramatu liturgicznego” „Roczniki Humanistyczne" 12 (1964), z. 1: 5-69.

MożDżan, Krzysztof. „Zarys dziejów opieki zdrowotnej i społecznej na Ziemi Przeworskiej do 1945 roku". Przeworskie Zapiski Historyczne, red. Władysław Dziedzic, t. II. Przeworsk: Towarzystwo Miłośników Przeworska, 1995.

Mróz, Franciszek. „Sanktuaria i kaplice Bożego Grobu w Polsce”. Peregrinus Cracoviensis 2000, z. 8: 79-114.

Muraszko, Michał, i Monika BiaŁKowska. „Gnieźnieńscy bożogrobcy”. Przewodnik Katolicki. Dostęp 12.10.2020. https://www.przewodnik-katolicki.pl/Archiwum/2012/Przewodnik-Kato licki-45-2012/Archidiecezja-Gnieznienska/Gnieznienscy-bozogrobcy

Niesiecki, Kasper. Herbarz Polski. Warszawa: WAiF, 1979 (repr.).

OBERTyŃski, Zdzisław. „Ślad tzw. św. ognia jerozolimskiego w liturgii śląskiej”. Sprawozdania Towarzystwa Naukowego Warszawskiego. Warszawa 1938. 
„Order of the Holy Sepulchre of Jerusalem". The Holy See. Dostęp 20.07.2020. http:// www.vatican.va/roman_curia/institutions_connected/oessh/en/cenni_storici_en.html.

PĘCKowski, Zbigniew. „Bożogrobcy. W Polsce”. W: Encyklopedia katolicka. T. 2, kol. 879-881. Lublin: TN KUL, 1989.

Pє̨cKowski, Zbigniew. Miechów. Studia z dziejów miasta i ziemi miechowskiej do roku 1914. Kraków: Wydawnictwo Literackie, 1967.

PĘKALSKI, Piotr. O początku, rozkrzewianiu i upadku Zakonu XX. Kanoników Stróżów Świętego Grobu Jerozolimskiego. Kraków: W drukarni C.K. Uniwersytetu Jagiellońskiego, 1867 (repr. Mielec: Zakład Poligraficzny Z. Gajek, 2013).

Piwoński, Henryk. „Bożogrobcy. Liturgia”. W: Encyklopedia katolicka. T. 2, kol. 881-002. Lublin: TN KUL 1976

PIwoŃSki, Henryk. „Liturgia wielkanocna u bożogrobców miechowskich”. „Roczniki Teologiczno-Kanoniczne" 16 (1969), z. 4: 100-102.

PIWoŃSKI, Henryk. „Liturgia wielkosobotnia u bożogrobców”. Studia Theologica Varsaviensia 10 (1971), nr 2: 131-146.

PIwoŃSKi, Henryk. „Liturgia wielkoczwartkowa u bożogrobców”. Archiwa, Biblioteki i Muzea Kościelne" 35 (1977).

PodgórsKa-KLawe, Zofia. Od hospicjum do współczesnego szpitala. Warszawa: Zakład Narodowy im. Ossolińskich, 1981.

Podleś, Antoni. „Dzieje czterdziestogodzinnego nabożeństwo w Polsce”. W: Studia z dziejów liturgii w Polsce, red. Wacław Schenk. T. 4. Lublin: TN KUL, 1982.

SkoRowsKi, Henryk. Protoplaści rodu Jaxa Bykowskich. Warszawa: UKSW, 2017.

Smereka, Władysław. Drogi Krzyżowe. Rys historyczny i teksty. Studium pasyjne. Kraków: Polskie Towarzystwo Teologiczne, 1968.

Surdacki, Marian. „Szpitalnictwo zakonne w średniowiecznej Polsce”. Roczniki Humanistyczne 63 (2015), z. 2: 49-98. DOI: 10.18290/rh.2015.63.2-3

„Symbolika Bożogrobców według relacji Chorzowskiego Bractwa Rycerskiego Bożogrobców”. Dostęp 10.01.2020. http://www.bozogrobcy.pl/symbolika-bozogrobcow.html.

TALBIERSKA, Jolanta. „Treści ideowe dekoracji monumentalnych kościoła Świętych Apostołów Piotra i Pawła w Nysie, dawniej kościoła klasztornego bożogrobców”. „Studia Theologica Varsaviensia”, 23 (1985), nr 1: 171-218.

ToBiasz, Mieczysław. „Bożogrobcy w Miechowie (w 800-lecie sprowadzenia do Polski)”. Nasza Przeszłość 17 (1963): 5-60.

TrajDos, Tadeusz. „Miechowici na ziemi przemyskiej za panowania Władysława Jagiełły”. Folia Historica Cracoviensia 4-5 (1997-1998): 67-98. DOI: 10.15633/fhc.1311.

United States Leutenancies. „History of the Order.” Dostęp 12.10.2020. http://www.holysepul chre.net/ history/history.html.

Urzejowice - między mitem a historia, red. Jadwiga Orzechowska. Urzejowice: Stowarzyszenia „Urzejowice”, 2011.

WachHolz, Leon: Szpitale krakowskie 1220-1920. Cz. 1-2. Kraków: Towarzystwo Miłośników Historii i Zabytków Krakowa, 1921-1924.

Wawoczny, Grzegorz. „Przy zamku stał kiedyś Grób Pański na wzór jerozolimskiego, a przy pl. Mostowym klasztor bożogrobców”. Nasz Racibórz. Dostęp 19.07.2020. https://www. nasz raciborz.pl/site/art/5-styl-zycia/14-historia/73208-przy-zamku-stal-kiedys-grob-panski-nawzor- jerozolimskiego--a-przy-pl--mostowym-klasztor-bozogrobcow”. 
Wprowadzenie do liturgii, red. Franciszek Blachnicki, Wacław Schenk i Rudolf Zielasko. Poznań: Księgarnia Św. Wojciecha, 1967.

ZвROŻEK, Jarosław. „Jan Amor Tarnowski (1488-1561) - hetman wielki koronny i właściciel miasta Tarnowa", Moje miasto Tarnów, 4.04.2013. Dostęp 19.07.2020. http://www.mmtarnow.com/ 2013/04/jan-amor-tarnowski-1488-1561-hetman.html.

\section{DZIAŁALNOŚĆ RELIGIJNA I DOBROCZYNNA \\ PRZEWORSKIEGO OŚRODKA KANONIKÓW REGULARNYCH STRÓŻÓW NAJŚWIĘTSZEGO GROBU BOŻEGO W JEROZOLIMIE}

\section{Streszczenie}

Tradycja dobroczynności zakonu bożogrobców w Polsce jest jednym z ciekawszych wątków tego opracowania. Zakon ten po raz pierwszy w tej części Europy wprowadził profesjonalny system leczenia szpitalnego dla ubogich. Rodzina magnacka Tarnowskich, kierując się polityką dworu królewskiego Jagiellonów, umacniała chrystianizację ziem Rusi Czerwonej od 1394 (1396) i otrzymała zgodę na sprowadzenie Kanoników Regularnych Stróżów Najświętszego Grobu w Jerozolimie do ośrodka duszpasterskiego w Przeworsku. Związek między zabudowaniami Grobu Bożego a liturgią i rozbudowanymi formami kultu Grobu Bożego miał swój specyficzny i oryginalny charakter. O ile kaplice Grobu Świętego związane z kalwariami i poszczególne przedstawienia Grobu nienależące do Miechowitów były miejscem kultu Męki Pańskiej, o tyle w przypadku przedstawień Grobu Świętego u bożogrobców ich związek z kultem i liturgią miał głębszy sens. Grób Pański w Przeworsku był i jest nie tylko zabytkiem architektonicznym, ale także miejscem żywego kultu religijnego. Przez blisko trzy stulecia istnienia przeworskiego Sepulchrum Domini spotykano różne formy kultu Grobu Pańskiego, zarówno w formie kultu liturgicznego, jak i paraliturgicznego, dlatego w pracy omówiono je bardziej szczegółowo. W dzisiejszych czasach szczególnie ważne dla kontynuacji tradycji średniowiecznych bractw religijnych kultywujących istotę Bożego Grobu są zorganizowane grupy młodych mężczyzn, a ostatnio także kobiet, które tworzą oddziały „Turków”, pełniących straż przy Bożym Grobie. W Przeworsku i okolicznych wsiach są one nadal widoczne, zwłaszcza w okresie wielkanocnym, zapewniając porządek w czasie uroczystości religijnych i pobożnego nawiedzania kościołów przez wiernych.

Słowa kluczowe: zakon bożogrobców; Przeworsk; Triduum Paschalne; Wielkanoc; obyczaje religijne; Straż Grobowa.

\section{RELIGIOUS AND CHARITABLE ACTIVITY \\ OF THE PRZEWORSK CENTER OF CANONS REGULARS \\ OF THE HOLY SEPULCHER OF JERUSALEM}

\section{S u m m a r y}

The very tradition of this order in Poland is one of the more interesting threads of this story. This order introduced, for the first time in this part of Europe, a professional system of hospital treatment for the poor. The magnate family of Tarnowskis, following the policy of the royal court of strengthening the Christianization of the territory of Red Ruthenia in 1394 (1396), received permission to bring the Holy Sepulcher Order (in Poland also called, from the first seat in Miechów, Miechowites) to a pastoral center in Przeworsk in the Church of St. Catherine. The 
relationship between the Holy Sepulcher buildings and the liturgy and other forms of worship of the Holy Sepulcher had its specific and original character. While the chapels of the Holy Sepulcher associated with Calvary and individual representations of the Tomb that did not belong to the Miechowites were places of the Lord's Passion cult, in the case of the representations of the Holy Sepulcher their relationship with worship and liturgy had a deeper basis. The Lord's Tomb in Przeworsk was and is not only an architectural monument, but also an object and place of a living religious cult. However, during the nearly three centuries of existence of the Przeworsk Sepulchrum Domini, we have come across various forms of worship of the Holy Sepulcher, both in the form of liturgical worship and non-liturgical worship, so it is worth discussing them here in more detail. Nowadays, especially important for the continuation of the tradition of the medieval brotherhoods of the Holy Sepulcher, in a sense, are organized groups of young men, and recently, exceptionally also women, who make up the "Turks." In the vicinity of Przeworsk, they are still particularly visible, especially during the Holy Week.

Key words: Order of the Holy Sepulcher; Przeworsk; Paschal Triduum; Easter; religious customs; Grave Guard. 